\title{
Structural and Functional Stabilization of Sericin from Bombyx mori Cocoons in a Biopolysaccharide Film: Bioorigami for Skin Regeneration
}

\author{
Victor M. Balcão, ${ }^{a, b}$ Liliam K. Harada, ${ }^{a}$ Ludmilla R. Jorge,${ }^{a}$ José M. Oliveira Jr., ${ }^{a}$ \\ Matthieu Tubino ${ }^{*, c}$ and Marta M. D. C. Vila ${ }^{\circledR *, a}$
${ }^{a}$ Laboratório de Biofilmes e Bacteriófagos, Universidade de Sorocaba, 18023-000 Sorocaba-SP, Brazil
${ }^{b}$ Centre for Environmental and Marine Studies and Department of Biology, University of Aveiro, Campus de Santiago, 3810-193 Aveiro, Portugal

'Instituto de Química, Universidade Estadual de Campinas, 13083-970 Campinas-SP, Brazil

\begin{abstract}
Development and optimization of a bioorigami film with silk sericin was pursued for skin regeneration. Several formulations were produced, with varying integrated sericin contents, viz. 0,1 , 2, 5, 10, 20 and $50 \mathrm{mg}_{\text {sericin }} \mathrm{mL}_{\text {film }}{ }^{-1}$. The physico-chemical characteristics of the bioorigami films produced were evaluated via infrared spectrophotometry, X-ray diffraction, X-ray transmission, $\mathrm{X}$-ray fluorescence, thermogravimetry, differential scanning calorimetry, transdermal protein permeation, kinetics of protein release from the bioorigami films and free radical scavenging activities. The mechanical resistance was also evaluated. The results by 2,2-diphenyl-1-picrylhydrazil (DPPH) assay suggest that the bioorigami films integrating crude sericin extract had capacity to sequester free radicals, exhibited prolonged release of the bioactive protein, good physico-chemical characteristics and adequate mechanical resistance. Specifically, the bioorigami film with $10 \mathrm{mg}_{\text {sericin }} \mathrm{mL}_{\text {film }}^{-1}$ proved to be able to release all the bioactive protein in a $12 \mathrm{~h}$ timeframe. The results suggest potential for use in biopharmaceutical application, specifically, as material for use in hydrogels.
\end{abstract}

Keywords: sericin, Bombyx mori, polysaccharide film, antioxidant activity, transdermal permeation, kinetics of protein release

\section{Introduction}

Biopolysaccharide films can be considered controlled release systems for drugs of topical application, depending on both the type of formulation and application in which they are used, ${ }^{1}$ being three-dimensional networks of hydrophilic biopolymers which, upon contact with a moist surface, swell and may release the drug by different mechanisms. ${ }^{2}$ Hence, biopolysaccharide films are of particular interest in the treatment of damaged skin due to their intrinsic low toxicity, potential for extended release of drugs and ability to keep the skin hydrated. ${ }^{3-5}$ Poly(vinyl alcohol), also known as polyvinyl alcohol (PVA) (used to produce hydrogels aiming at the treatment of topical ulcers), is a non-toxic, biocompatible polymer which has excellent film forming properties and ease of processability, as well as mechanical, thermal and chemical resistances. ${ }^{5-8}$

*e-mail: tubino@iqm.unicamp.br; marta.vila@prof.uniso.br
Considering the growing importance of hydrogels as pharmaceutical forms for controlled release of drugs, the aim of the present research work was to develop and evaluate a biopolysaccharide film, herein coined as a bioorigami film due to the intended characteristics and mode of use. For this, it was used PVA, carrageenan and xanthan gums as raw materials, containing incorporated silk sericin extracted from Bombyx mori cocoons, for antioxidant topical applications. Sericin from the cocoons of the silkworm Bombyx mori is a water-soluble globular glycoprotein, collectively representing a family of proteins with molecular weights ranging from ca. 10 to ca. $310 \mathrm{kDa}^{9}$ or from 20 to $400 \mathrm{kDa} .{ }^{10,11}$ Sericin is primarily amorphous and water soluble, acting as a gum binder to maintain the structural integrity of the cocoon. ${ }^{12}$ Sericin is rich in serine (ca. 32\%), aspartic acid (ca. 16.8\%) and glycine (ca. 8.8\%), and thus possesses a high concentration of hydroxyl groups. ${ }^{13}$ Sericin has been found to exhibit several biological (beneficial) activities, spanning from 
antityrosinase properties, promotion of collagen production (important in wound healing applications on both skin and corneal tissues), anti-inflammatory activity, antitumoural activity, anti-ageing and anti-wrinkle, antimicrobial, use in controlled drug-releasing biomaterials to promote stability and prolonged release, to antioxidant. ${ }^{14}$ Due to the uniqueness of this globular protein (representing in fact a family of proteins), silk sericin has great potential to be used in biopharmaceutical products. ${ }^{14}$ Hence, silk sericin was considered in this research as a new potentially valuable skin regeneration product, following a previous research ${ }^{14}$ entailed with the major goal of extracting and characterizing this potential multipurpose protein. The optimized bioorigami film formulations integrating silk sericin was subsequently characterized physicochemically, encompassing determination of pore size and porosity via $\mathrm{X}$-ray tomography, surface morphology via field emission scanning electron microscopy (FESEM), thermal analyses via thermogravimetry (TGA) and differential scanning calorimetry (DSC), infrared spectrophotometry with Fourier transform (FTIR), X-ray computed tomography, energy dispersive X-ray fluorescence (EDXRF), X-ray diffraction analyses (XRD), transdermal permeation studies and kinetics associated with the sericin release process.

\section{Experimental}

\section{Materials}

\section{Chemicals}

All reagents used were of analytical grade and were used without further purification. Tap water was purified in a Master System All (model MS2000, Gehaka, São Paulo, $\mathrm{SP}$, Brazil) to a final resistivity of ca. $18.18 \mathrm{M} \Omega \mathrm{cm}$ and conductivity of $0.05 \mu \mathrm{S} \mathrm{cm}{ }^{-1}$. Sericin (Sigma S5201-1G), Coomassie Brilliant Blue G250 (ref. Sigma 27815-25G-F), ortho-phosphoric acid (85\%, v/v; Sigma V000145-1L), Uvasol $^{\text {TM }}$ ethanol for spectroscopy $(99.8 \%$, v/v; Sigma 32205-1L), methylparaben (Sigma 47889) and DPPH (2,2-diphenyl-1-picrylhydrazyl) (Sigma D9132-1G), were purchased from Sigma-Aldrich (St. Louis, MO, USA). Polyvinyl alcohol (PVA) with a hydrolysis degree of 98\% (PVA98) was purchased from Neon Comercial Ltda. (Suzano, SP, Brazil). Glycerol was purchased from Cinética (Jandira, SP, Brazil). Carrageenan (Genuvisco ${ }^{\circledR}$ CG-131) and xanthan (Xantural ${ }^{\circledR}$ 180) gums were a kind gift from CPKelco (Limeira, SP, Brazil). Methylparaben was acquired from Synth (Diadema, SP, Brazil).

\section{Biological materials}

The Bombyx mori cocoons were a kind gift from
Fiação de Seda Bratac S.A. (Londrina, PR, Brazil). The bacterial strains utilized in the antimicrobial assays were Staphylococcus aureus CCCD-S007 (Coleção de Cultura Cefar Diagnóstica-Staphylococcus 007), Pseudomonas aeruginosa CCCD-P004 (Coleção de Cultura Cefar Diagnóstica-Pseudomonas007), and Escherichia coli CCCD-E003 (Coleção de Cultura Cefar DiagnósticaEscherichiaE003), supplied by Cefar Diagnóstica (Jurubatuba, SP, Brazil). The microbiological growth media utilized were BHI (brain heart infusion) from HiMedia Laboratories (Mumbai, India) and TSA (tryptic soy agar) from Kasvi (Curitiba, PR, Brazil).

\section{Procedures}

\section{Extraction of sericin}

Sericin was extracted from the cocoons of Bombyx mori following the procedure described in elsewhere. ${ }^{14}$

Experimental factorial design for optimization of plain bioorigami films with appropriate mechanical properties

The $3^{2}$ full factorial design approach are shown in Table 1. The two different variables (carrageenan and xanthan gum concentrations) at three levels each, low (-1), medium/central (0) and high (+1), and their influence upon the mechanical properties of the biopolysaccharidic films produced (BPFi) were studied.

Table 1. Full $3^{2}$ factorial design, providing the lower $(-1)$, central $(0)$ and upper (+1) level values for each variable

\begin{tabular}{lccc}
\hline \multirow{2}{*}{ Independent variable } & \multicolumn{3}{c}{ Level } \\
\cline { 2 - 4 } & Low level & Central level & Upper level \\
\cline { 2 - 4 } & $(-1)$ & $(0)$ & $(+1)$ \\
\hline Carrageenan gum $/(\%, \mathrm{~m} / \mathrm{m})$ & 0.750 & 1.500 & 2.250 \\
Xanthan gum $/(\%, \mathrm{~m} / \mathrm{m})$ & 0.250 & 0.500 & 0.750 \\
\hline
\end{tabular}

All formulations were produced integrating constant amounts of PVA $(1.25 \%, \mathrm{~m} / \mathrm{m}$; to induce polymerization), glycerol $(2.50 \%, \mathrm{~m} / \mathrm{m}$; to induce plasticity) and methylparaben $(0.1 \%, \mathrm{~m} / \mathrm{m}$; to inhibit fungal growth), thus yielding nine (plain) biopolymeric film formulations (Table 2).

After determination of the optimal biopolysaccharidic levels leading to a suitable film in terms of mechanical properties (viz., adequate resistance to traction and perforation, and resilience) while maintaining a good level of malleability, such levels were used for production of different films with varying amounts of sericin. Hence, a total of seven films were produced integrating sericin according to the data included in Table 3. 
Table 2. Composition of the plain bioorigami films for optimization of the appropriate mechanical properties

\begin{tabular}{|c|c|c|c|c|c|c|c|}
\hline \multicolumn{2}{|c|}{ Carrageenan gum } & \multicolumn{2}{|c|}{ Xanthan } & \multirow{2}{*}{$\mathrm{PVA} / \mathrm{g}$} & \multirow{2}{*}{ Glycerol / g } & \multirow{2}{*}{ Methylparaben / g } & \multirow{2}{*}{ Ultrapure water / g } \\
\hline Level & Mass / g & Level & Mass / g & & & & \\
\hline$(-1)$ & 0.075 & $(-1)$ & 0.025 & 0.125 & 0.250 & 0.010 & 9.515 \\
\hline$(-1)$ & 0.075 & $(0)$ & 0.050 & 0.125 & 0.250 & 0.010 & 9.490 \\
\hline$(-1)$ & 0.075 & $(+1)$ & 0.075 & 0.125 & 0.250 & 0.010 & 9.465 \\
\hline (0) & 0.150 & $(-1)$ & 0.025 & 0.125 & 0.250 & 0.010 & 9.440 \\
\hline (0) & 0.150 & $(0)$ & 0.050 & 0.125 & 0.250 & 0.010 & 9.415 \\
\hline (0) & 0.150 & $(+1)$ & 0.075 & 0.125 & 0.250 & 0.010 & 9.390 \\
\hline$(+1)$ & 0.225 & $(-1)$ & 0.025 & 0.125 & 0.250 & 0.010 & 9.365 \\
\hline$(+1)$ & 0.225 & (0) & 0.050 & 0.125 & 0.250 & 0.010 & 9.340 \\
\hline$(+1)$ & 0.225 & $(+1)$ & 0.075 & 0.125 & 0.250 & 0.010 & 9.315 \\
\hline
\end{tabular}

PVA: polyvinyl alcohol; in bold: best composition for the bioorigami.

Table 3. Composition of the several bioorigami films integrating variable amounts of sericin

\begin{tabular}{lccccccc}
\hline Bioorigami No. & $\begin{array}{c}\text { Carrageenan } \\
\text { gum / g }\end{array}$ & $\begin{array}{c}\text { Xanthan } \\
\text { gum / g }\end{array}$ & PVA / g & Glycerol / g & Methylparaben / g & Sericin / g & Ultrapure water / g \\
\hline Bioo1 & 0.225 & 0.050 & 0.125 & 0.250 & 0.010 & 0.000 & 9.340 \\
Bioo2 & 0.225 & 0.050 & 0.125 & 0.250 & 0.010 & 0.010 & 9.330 \\
Bioo3 & 0.225 & 0.050 & 0.125 & 0.250 & 0.010 & 0.020 & 9.320 \\
Bioo4 & 0.225 & 0.050 & 0.125 & 0.250 & 0.010 & 0.050 & 9.290 \\
Bioo5 & 0.225 & 0.050 & 0.125 & 0.250 & 0.010 & 0.100 & 9.240 \\
Bioo6 & 0.225 & 0.050 & 0.125 & 0.250 & 0.010 & 0.200 & 9.140 \\
Bioo7 & 0.225 & 0.050 & 0.125 & 0.250 & 0.010 & 0.500 & 8.840 \\
\hline
\end{tabular}

PVA: polyvinyl alcohol; Bioo: bioorigami.

\section{Moisture content analyses via infrared heating}

Moisture content determination of the bioorigami films was carried out in an infrared moisture analyzer from Shimadzu (model MOC63U, Kyoto, Japan) in "slow" mode. For the moisture determinations, $20 \mathrm{mg}$ samples of the bioorigami films were heated up to $120^{\circ} \mathrm{C}$.

\section{FTIR-ATR analyses}

The FTIR-ATR (attenuated total reflectance) spectra of bioorigami films integrating sericin were gathered using a Fourier Transform Infrared 100 Spectrophotometer from Agilent (model Cary 630, Santa Clara, CA, USA), in the wavenumber range from 4000 to $400 \mathrm{~cm}^{-1}$, with a resolution of $2 \mathrm{~cm}^{-1}$, and using Happ-Genzel apodization.

\section{XRD analyses}

X-ray diffractograms of bioorigami films integrating sericin were gathered in an X-ray diffractometer from
Shimadzu (model XRD7000, Kyoto, Japan), using $\mathrm{X}$-ray radiation from a copper lamp with radiation $\mathrm{K} \alpha$ $(\lambda=1.5418 \AA$ ) filtered through a $\mathrm{Cu}$ target. The X-ray scanning was performed at diffraction angles of $2 \theta$ (from 5 to $90^{\circ}$, with increments of $0.02^{\circ}$ and rate of $2^{\circ} \mathrm{min}^{-1}$ ), with a voltage of $40 \mathrm{kV}$, electric current intensity of $30 \mathrm{~mA}$, and $\mathrm{X}$-ray power of $3 \mathrm{~kW}$.

\section{TGA and DSC analyses}

The TGA analyses were carried out using a thermogravimeter from TA Instruments (model 2050, New Castle, USA). The DSC analyses were carried out using a differential scanning microcalorimeter from TA Instruments (model MDSC 2910, New Castle, USA). Thermal characterization of bioorigami films integrating sericin followed the procedure described by Rocha et al. ${ }^{14}$ The samples were subjected to a linear temperature increase from ca. 20 up to $250{ }^{\circ} \mathrm{C}$, at a constant heating rate of $10{ }^{\circ} \mathrm{C} \mathrm{min}^{-1}$, under an inert atmosphere maintained with a

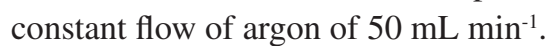




\section{Protein quantification via modified Bradford method}

A modification of the Bradford method for protein quantification was used according to the procedure described by Robyt and White ${ }^{15}$ and Balcão et al. ${ }^{16}$ Aliquots of $500 \mu \mathrm{L}$ of the receiving fluid (phosphate buffer, $\mathrm{pH}$ 7.4) in the Franz cells were added to $4.5 \mathrm{~mL}$ of the working solution of Coomassie Brilliant Blue G-250 (prepared according to the procedure described elsewhere), ${ }^{15,16}$ incubated at room temperature for $5 \mathrm{~min}$ and absorbance was measured at $595 \mathrm{~nm}\left(\mathrm{Abs}_{595 \mathrm{~nm}}\right)$ using disposable plastic cuvettes (Kartell) in a UV-Vis Spectrophotometer from Agilent (model Cary 60 UV-Vis, Santa Clara, CA, USA). A calibration curve for protein was prepared using solutions of bovine serum albumin (BSA) in phosphate buffer ( $\mathrm{pH} 7.4)$ at several concentrations $\left(\mathrm{C}_{\text {prot }}\right)$ in the range $0-1000 \mu \mathrm{g} \mathrm{mL}^{-1}: \mathrm{Abs}_{595 \mathrm{~nm}}=1.6554 \times \mathrm{C}_{\text {prot }} /\left(0.1922+\mathrm{C}_{\text {prot }}\right)$ (correlation coefficient $(\mathrm{r})=0.99529)$.

Evaluation of the free radical scavenging activity via the DPPH method

The potential for free radical scavenging activity of the bioorigami films using the DPPH reagent was evaluated by a method described by Wu et al. ${ }^{17}$ Amarowicz et al. ${ }^{18}$ and Caetano et al. ${ }^{19}$ with slight modifications. To $10 \times 10 \mathrm{~mm}$ square samples of the bioorigami films, $3500 \mu \mathrm{L}$ of freshly prepared DPPH radical in a methanol solution $\left(1.0 \times 10^{-4} \mathrm{~mol} \mathrm{~L}^{-1}\right)$ was added. After reaction for $25 \mathrm{~min}$ at room temperature $\left(25^{\circ} \mathrm{C}\right)$, in the dark, the reaction mixtures were centrifuged at $6400 \mathrm{rpm}$ for $5 \mathrm{~min}$. The decolorizing result of the supernatant was then assayed spectrophotometrically at $517 \mathrm{~nm}$ and compared with a blank control containing bioorigami film and pure methanol instead of DPPH. In addition, a blind control containing methanol and ultrapure water instead of bioorigami film $(500 \mu \mathrm{L}$ ultrapure water added to $3500 \mu \mathrm{L}$ of methanol) was also assayed. Calculation of free radical scavenging activity was carried out using the equation Scavenging activity $(\%)=\left(1-\frac{\mathrm{Abs}_{\text {sample }}}{\mathrm{Abs}_{\text {blind }}}\right) \times 100$, where scavenging activity refers to the free radical scavenging percentage, $\mathrm{Abs}_{\text {sample }}$ refers to the absorbance of the bioorigami film at $517 \mathrm{~nm}$, and $\mathrm{Abs}_{\text {blind }}$ refers to the absorbance of the blind control at $517 \mathrm{~nm}$. Ascorbic acid at a concentration of $0.5 \mathrm{mg} \mathrm{mL}^{-1}$ was used for comparison of results. The spectrophotometer was zeroed with plain ultrapure water.

\section{Mechanical resistance properties}

Mechanical properties of the bioorigami films were evaluated using a texturometer from Stabile Micro Systems (model TA-TX Plus, Godalming, United Kingdom), evaluating parameters such as resistance to perforation, resistance to traction, and resillience. The determination parameters were set as distance of $5 \mathrm{~mm}$ for the perforation resistance tests, distance of $2 \mathrm{~mm}$ for both resillience and relaxation tests, and a maximum force of $5 \mathrm{~kg}$ for all tests. All determinations were performed in triplicate. Sample dimensions were $2 \times 5 \mathrm{~cm}$ for resistance to traction, and $2 \times 2 \mathrm{~cm}$ for resistance to perforation and resilience.

Transdermal permeation and kinetics of protein release from the bioorigami films

The sericin release capability of the several bioorigami films was evaluated via transdermal permeation studies in a DHC-6T Transdermal System from Logan Instruments Corp. (Somerset, NJ, USA). For these assays, thawed porcine ear skin disks $\left(0.5 \mathrm{~mm}\right.$ thick $\times 30 \mathrm{~mm} \phi_{\text {ext }}$ (external diameter)) were cut and clamped in place between the acceptor and donor chambers on top of the Franz diffusion cell support (possessing a central hole with $15 \mathrm{~mm} \phi_{\text {ext }}$ ). On top of these porcine ear skin disks, a disk of bioorigami film with the same external diameter $\left(30 \mathrm{~mm} \phi_{\text {ext }}\right)$ was carefully placed eliminating any air bubbles, and 3 droplets of phosphate buffer ( $\mathrm{pH}$ 7.4) were added so as to moisturize the bioorigami film. To the bottom glass receptacle of the Franz diffusion cell (possessing a small cylindrical Teflon-coated magnetic stirring bar), $8 \mathrm{~mL}$ of (degassed) phosphate buffer ( $\mathrm{pH}$ 7.4) were carefully injected until touching the lower surface of the porcine ear skin disk. The porcine ear skin was carefully prepared according to the procedure described by Salerno et al.,${ }^{20}$ using skin with its full-thickness for guaranteeing integrity. At pre-determined time intervals (viz., 0, 0.25, 0.50, 1, 3, 6, 9, and $12 \mathrm{~h}$ ), $2 \mathrm{~mL}$ samples were withdrawn from the receiving fluid beneath the porcine ear skin disk, and $2 \mathrm{~mL}$ of fresh phosphate buffer ( $\mathrm{pH}$ 7.4) were duly added so as to reset the volume. Each sample was then assayed for protein quantification via the modified Bradford method, as described earlier.

Study of the kinetics of protein release from the bioorigami films

The protein release experiments were carried out by measuring the concentration of protein in a phosphate buffer ( $\mathrm{pH} 7.4$ ) medium contact with the lower surface of bioorigami films. Bioorigami disks $\left(0.5 \mathrm{~mm}\right.$ thick $\left.\times 30 \mathrm{~mm} \phi_{\text {ext }}\right)$ were cut obtaining different protein levels according to Table 4. The lower surfaces of the film samples were placed in contact with $8 \mathrm{~mL}$ of phosphate buffer $(\mathrm{pH} \mathrm{7.4)}$ at room 
temperature $\left(25 \pm 0.1^{\circ} \mathrm{C}\right)$. At pre-determined time intervals, aliquots from the phosphate buffer $(\mathrm{pH} 7.4)$ contact with the bioorigami films were withdrawn and assayed for protein content via the modified Bradford method as described earlier. The experiments were terminated when a protein concentration plateau was reached.

Table 4. Amount of protein from the bioorigami films for the study of the kinetics of protein release

\begin{tabular}{lc}
\hline $\begin{array}{l}\text { Bioorigami films with many } \\
\text { different amount of protein }\end{array}$ & Protein of bioorigami films / mg \\
\hline $1 \mathrm{mg}_{\text {sericin }} \mathrm{mL}_{\text {film }}{ }^{-1}$ & 0.0325 \\
$2 \mathrm{mg}_{\text {sericin }} \mathrm{mL}_{\text {film }}{ }^{-1}$ & 0.1108 \\
$50 \mathrm{mg}_{\text {sericin }} \mathrm{mL}_{\text {film }}{ }^{-1}$ & 0.2685 \\
\hline
\end{tabular}

Determination of elemental composition by EDXRF analyses

The elemental composition of selected bioorigami films loaded with variable amounts of sericin was determined using an X-ray fluorescence spectrometer with energy dispersion (EDXRF) from Amptek (Bedford, Massachusetts, USA), which comprised an Ag anode and a $25 \mathrm{~mm}^{2} \mathrm{SDD} X$-ray detector with a resolution of $128 \mathrm{eV}$ at the $\mathrm{Mn} \mathrm{K} \alpha$ line. The voltage applied to the X-ray tube was of $30 \mathrm{kV}, 10 \mu \mathrm{A}$ of current, with $10 \%$ lag time in the detector. All measurements were carried out using atmospheric air, and the measuring time was set at $300 \mathrm{~s}$ (live time) for each sample. A collimator with an aperture of $1 \mathrm{~mm}$ was used in the exit of the X-ray source. The spectra were gathered sequentially, with a resolution of $0.02 \mathrm{keV}$, from 0 to $30 \mathrm{keV}$.

\section{Tomographic analyses via X-ray transmission (XRT)}

The tomographic images of the bioorigami film samples were gathered using a $3^{\text {rd }}$ generation computed X-ray transmission tomograph ${ }^{21}$ from Bruker microCT (model SkyScan 1174, Kontich, Belgium). The bioorigami film samples were fixed in a hollow support and placed inside the tomograph chamber, and image slices were gathered using the following configurations of the tomographic system: operating voltage set at $35 \mathrm{kV}$ and electric current with $661 \mu \mathrm{A}$. The bioorigami film samples were rotated $180^{\circ}$, with angular increments of $0.8^{\circ}$, producing 225 radiographs (projections) per image, each containing $1304 \times 1304$ (width $\times$ height) pixels with a spatial resolution of $6.92 \mu \mathrm{m}$. The exposure time per projection was $5000 \mathrm{~ms}$. At the outlet of the X-ray source one utilized an Al filter with $0.25 \mathrm{~mm}$ thickness. Having all the projections (radiographs gathered at each angular position), one utilized the software NRecon ${ }^{\mathrm{TM}}$ from Bruker (version 1.6.9.4, Kontich, Belgium), ${ }^{22}$ which uses the algorithm of Feldkamp et al. $^{23}$ in the process of reconstructing the tomographic images, and the software CTVox ${ }^{\mathrm{TM}}$ (version 2.6.0 r908-64bit, from Bruker microCT), ${ }^{22} \mathrm{CTan}^{\mathrm{TM}}$ (version 1.13.5.1-64bit, from Bruker microCT) ${ }^{22}$ and CTvol (version 2.2.3.0-64bit, from Bruker microCT) ${ }^{22}$ for processing the tomographic images.

\section{Dispersive energy scanning electron microscopy analyses (DESEM)}

The surface and morphology of the bioorigami films were observed in a dispersive energy scanning electron microscope (DESEM) from LEO Electron Microscopy/ Oxford (model Leo 440i, Cambridge, United Kingdom) equipped with an energy dispersive detector (EDS detector) (model 6070, Cambridge, United Kingdom). Samples of the bioorigami films were cut and sputter-coated with an Au film (92 A thickness) via cathodic pulverization on a carbon layer produced by evaporation in a metalizing device (Sputter Coater Polaron) from VG Microtech (model SC7620, Uckfield, United Kingdom). Microphotographs were gathered using electron beams with acceleration speeds of 10-20 keV via random scanning.

\section{Results and Discussion}

The biopolymeric film developed was coined "bioorigami" since its mechanical characteristics made it foldable, just like an origami, which in fact is desirable if topical application are sought in regions of the skin that are not entirely plane. In our opinion, the designation bioorigami intends to make an impact on the film's mechanical properties, without implying any rupture or desintegration of the biopolymeric matrix, and thus makes an extra appeal to the intended purpose of the film.

The experimental factorial design undertaken to define the best biopolysaccharide composition and associated mechanical properties for the bioorigami films (Table 1) yielded those of the level $(+1)(0)$ [(carrageenan gum) (xanthan gum)] as the best composition for the bioorigami films (Table 2, in bold). Departing from this (optimal) composition leading to bioorigami films with the highest values of resilience, resistance to perforation and resistance to traction, six bioorigami films were produced (Table 3) integrating the same factorial level of (carrageenan gum) (xanthan gum) (viz., (+1)(0)) and variable amounts of sericin (viz., 0, 1, 2, 5, 10, 20 and $50 \mathrm{mg}_{\text {sericin }} \mathrm{mL}_{\text {film }}{ }^{-1}$ ). In a review paper by Baker et al. ${ }^{24}$ these researchers claim that 
it is possible to produce soft hydrogels with ca. $10 \%(\mathrm{~m} / \mathrm{m})$ PVA and rigid hydrogels with ca. 50 to $60 \%$ (m/m) PVA. The major purpose of the research effort described herein was to produce a bioorigami biopolysaccharide film with malleability, although with a certain resistance so that it could be utilized for topical applications. The average moisture content of the several bioorigami films produced ranged between $56.81 \pm 0.44$ and $32.28 \pm 1.47 \%(\mathrm{~m} / \mathrm{m})$ for the bioorigami films integrating 0 and $50 \mathrm{mg}_{\text {sericin }} \mathrm{mL}_{\text {film }}{ }^{-1}$, respectively.

Sericin extraction from the silk cocoons of Bombyx mori was carried out as described in detail elsewhere. ${ }^{14}$

\section{Fourier transform infrared (FTIR) analyses}

The FTIR analyses are displayed in Figure 1.

Comparing the spectrum of lyophilized crude sericin extract (Figure 1a) with the spectrum of the plain bioorigami film (Figure 1b) and the spectra of the bioorigami films loaded with sericin (Figures 1c-1h), the same characteristic peaks can be observed with only minor variations in peak intensity, viz., at wavenumbers 1398, 1423, and $1409 \mathrm{~cm}^{-1}$. This suggests that the chemical aspect of sericin was preserved during integration into the bioorigami films. According to Gupta et al., ${ }^{25}$ protein molecules may present characteristic energy absorption between wavenumbers 1650 and $1630 \mathrm{~cm}^{-1}$ for primary amides, between wavenumbers 1540 and $1520 \mathrm{~cm}^{-1}$ for secondary amides and between wavenumbers 1270 and $1230 \mathrm{~cm}^{-1}$ for tertiary amides. From inspection of the transmittance spectra depicted in Figure 1a, one can observe peaks within the wavenumber range probably representing primary amides at approximately $1620 \mathrm{~cm}^{-1}$ due to the stretch of the carbonyl group $(\mathrm{C}=\mathrm{O})$, secondary amides at approximately $1519 \mathrm{~cm}^{-1}$ and tertiary amides in the region of $1238 \mathrm{~cm}^{-1}$ due to the stretch of the bond C-N. Additionally, the positions of these peaks confirm the protein, such as 1650 (random coil), and $1613 \mathrm{~cm}^{-1}$ (beta-sheet), for primary amide, 1540 (random coil) and $1520 \mathrm{~cm}^{-1}$ (beta-sheet) for secondary amide, and 1270 (beta-sheet) and $1230 \mathrm{~cm}^{-1}$ (random coil) for the tertiary amide. ${ }^{25}$ The bioorigami films (Figures $1 \mathrm{~b}-1 \mathrm{~h}$ ) produced very similar infrared spectra, irrespective of the presence of protein in the film, with a major peak produced between 3274 and $3308 \mathrm{~cm}^{-1}$, corresponding to $\mathrm{OH}$ groups in water, and another major peak at 1648 (Figure 1b), 1650 (Figure 1c), 1650 (Figure 1d), 1650 (Figure 1e), 1655 (Figure 1f), 1655 (Figure 1g), and $1639 \mathrm{~cm}^{-1}$ (Figure 1h) corresponding to a stretch of the $\mathrm{C}=\mathrm{O}$ group of primary amides, most likely due to the strong hydrophilic character of primary amides. The stretching vibrations observed in the region between $3274-3308 \mathrm{~cm}^{-1}{ }^{1}{ }^{26}$ probably is related to hydroxyl groups of

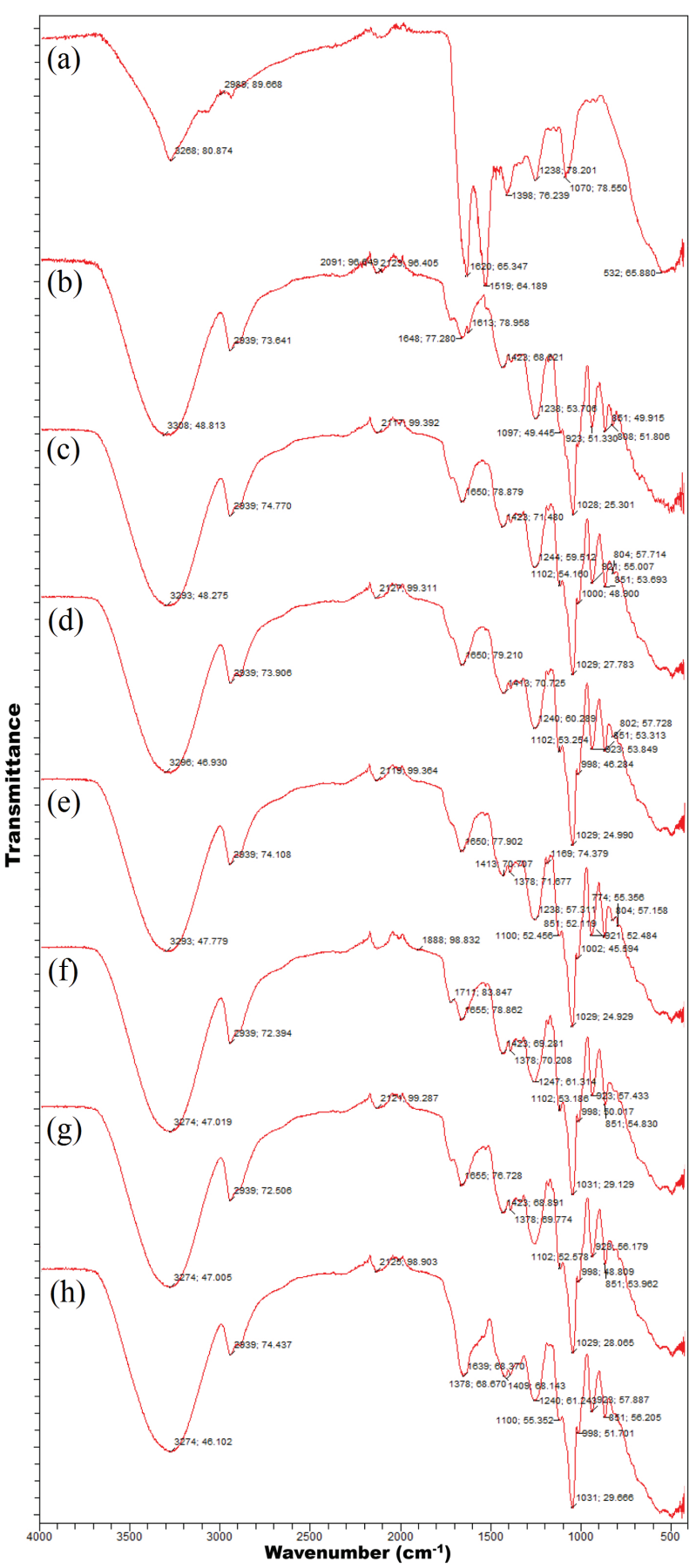

Figure 1. FTIR-ATR spectra of (a) lyophilized crude sericin extract; (b) plain bioorigami film; (c-h) bioorigami film with 1, 2, 5, 10, 20 and $50 \mathrm{mg} \mathrm{mL}^{-1}$ sericin, respectively.

water molecules. Characteristic peaks indicative of protein lie between 1390 to $1250 \mathrm{~cm}^{-1}$ for $\mathrm{C}-\mathrm{N}$ bonds, between 1640 and $1500 \mathrm{~cm}^{-1}$ for $\mathrm{N}-\mathrm{H}$ groupings, and between 3500 and $3300 \mathrm{~cm}^{-1}$ corresponding to $\mathrm{OH}$ groups in water. ${ }^{27}$ The infrared spectra displayed in Figure 1 may indicate that the chemical aspect of the protein moiety was preserved during production of the bioorigami films, allowing to suggest that the sericin protein did not engage in any chemical 
interactions with the bioorigami components, only being carried by the film, which otherwise could have reduced its antioxidant activity.

\section{Thermal analyses via TGA and DSC}

Mass decrements during heating were evaluated from thermogravimetric curves, whereas the temperature of the maximum rate of mass change $\left(\mathrm{T}_{\max }\right)$ was determined from the maximum of the $1^{\text {st }}$ derivative of the weight loss curves. According to Dandurand et al.,$^{28}$ the global trend of the thermogravimetric plot depicted in purple in Figure 2a (viz., lyophilized sericin) corresponds to the classical thermal behavior of a freeze-dried protein. The first stage, occurring between 25 and $100{ }^{\circ} \mathrm{C}$ (Figure 2a), is generally linked to the evaporation of water adsorbed to the protein moieties, and corresponds to ca. $10 \%$ of the total sericin sample mass. The second stage, occurring between 200 and $400{ }^{\circ} \mathrm{C}$ (Figure 2a) is associated with the degradation of the protein moieties in the sericin sample, namely the progressive deamination, decarboxylation and depolymerization arising from breaking of (poly)peptide bonds, and concomitant carbonization of the primary structure (between ca. 500 and $600{ }^{\circ} \mathrm{C}$ ).
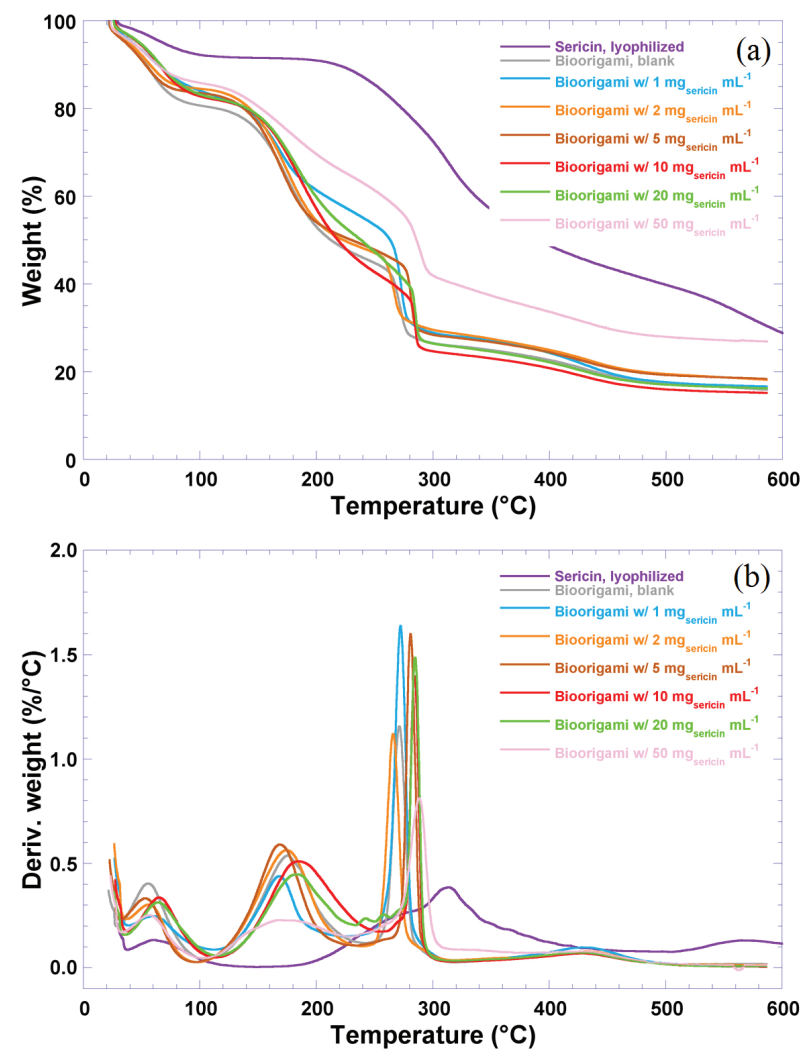

Figure 2. Thermogravimetric curves (a) and $1^{\text {st }}$ derivative of the weight loss curves (b) of lyophilized sericin extract (purple curve), blank bioorigami film (gray line), bioorigami film with 1, 2, 5, 10, 20, $50 \mathrm{mg} \mathrm{mL}^{-1}$ sericin (light blue, orange, brown, red, green, light pink curves, respectively).
The degradation of sericin consists of three well-marked steps as shown by three maxima on the $1^{\text {st }}$ derivative of the weight loss curve (see Figure $2 \mathrm{~b}$ ) at $\mathrm{T}_{\max 1}$ ca. $260^{\circ} \mathrm{C}$, $\mathrm{T}_{\max 2}$ ca. $320{ }^{\circ} \mathrm{C}$ and $\mathrm{T}_{\max 3}$ ca. $570{ }^{\circ} \mathrm{C}$. These results are in agreement with results published by Rocha et al.,$^{14}$ pertaining to thermogravimetric analysis of crude sericin extracts from plain Bombyx mori cocoons, and Dandurand et al. ${ }^{28}$ pertaining to the thermogravimetric analysis of peptide fragments. The $1^{\text {st }}$ derivative of the weight loss curve (i.e., the rate of mass change, Figure 2b) can be used to tell the points at which weight loss is most apparent (inflection points) (Table 5).

Table 5. Values of temperature of $1^{\text {st }}$ derivative obtained by thermogravimetric curves (TGA)

\begin{tabular}{ll}
\hline Sample & Temperature / ${ }^{\circ} \mathrm{C}$ \\
\hline Lyophilized sericin & $60,260,320,570$ \\
Plain bioorigami film & $60,180,270,430$ \\
Bioorigami film with $1 \mathrm{mg}_{\text {sericin }} \mathrm{mL}_{\text {film }}{ }^{-1}$ & $60,170,270,430$ \\
Bioorigami film with $2 \mathrm{mg}_{\text {sericin }} \mathrm{mL}_{\text {film }}{ }^{-1}$ & $60,175,265,430$ \\
Bioorigami film with $5 \mathrm{mg}_{\text {sericin }} \mathrm{mL}_{\text {film }}{ }^{-1}$ & $50,175,280,430$ \\
Bioorigami film with $10 \mathrm{mg}_{\text {sericin }} \mathrm{mL}_{\text {film }}{ }^{-1}$ & $70,190,290,430$ \\
Bioorigami film with $20 \mathrm{mg}_{\text {sericin }} \mathrm{mL}_{\text {film }}{ }^{-1}$ & $70,180,290,430$ \\
Bioorigami film with $50 \mathrm{mg}_{\text {sericin }} \mathrm{mL}_{\text {film }}{ }^{-1}$ & $60,170,290,430$ \\
\hline
\end{tabular}

In general, thermal analyses are useful tools in developing formulations since they allow evaluating the compatibility between components of a formulation and the stability and thermal decomposition of bioactive moieties. The data obtained by thermal analysis is directly related to the final quality of a (bio)pharmaceutical product, allowing to infer aspects of therapeutic efficacy of the product or the stability of the product throughout the shelf life (or validity) period. TGA accompanies the variation in sample mass as a function of a linear increase in temperature during a predetermined time interval, allowing to determine the thermal profile of the bioorigami films prepared. As can be observed from inspection of the curves in Figure 2b, the thermal behavior is quite similar for all bioorigami films, with a mass loss around $60{ }^{\circ} \mathrm{C}$ indicating loss of water. Between 160 and $190{ }^{\circ} \mathrm{C}$ and 260 and $300{ }^{\circ} \mathrm{C}$ the mass loss can be attributed to the decomposition of the polymer resulting in the carbonized residue. ${ }^{29}$ The results from DSC analyses of lyophilized sericin and plain and sericin-loaded bioorigami film samples, recorded under heating mode between 25 and $250{ }^{\circ} \mathrm{C}$, are displayed in Figure 3. The endothermic peak observed at $58.81{ }^{\circ} \mathrm{C}$ (lyophilized sericin sample sample, with associated melting enthalpy of $3.549 \mathrm{~J} \mathrm{~g}^{-1}$ ) may be considered as the first order 
transition commonly observed in a broad class of hydrated biopolymers such as proteins. By analogy with the work by Dandurand et al. ${ }^{28}$ this endothermic event is attributable to the evaporation of bound water molecules.

As already observed by TGA, degradation of the protein moieties began above $200{ }^{\circ} \mathrm{C}$. In the case of lyophilized sericin sample, the second major endothermic event is the sharp endothermic peak at $123.64{ }^{\circ} \mathrm{C}$ (with associated melting enthalpy of $146.8 \mathrm{~J} \mathrm{~g}^{-1}$ ), associated to order $\rightarrow$ disorder transitions, which can be considered as thermal signatures of protein (irreversible) denaturation. ${ }^{14}$ The third major endothermic event is the shallow endothermic peak at $219.87^{\circ} \mathrm{C}$ (with associated melting enthalpy of $28.06 \mathrm{~J} \mathrm{~g}^{-1}$ ), associated to degradation phenomena, which can be considered as thermal signature of protein carbonization.

The thermograms obtained (Figure 3 ) indicated that the presence of protein in the bioorigami films promoted a slight shift of the endothermic event next to $122.76^{\circ} \mathrm{C}$. It was also observed that increasing loadings of sericin in the bioorigami film also led to decreasing variations in the melting enthalpies (viz., $\Delta \Delta \mathrm{H}$ ) (Table 6). Since the several bioorigami films just differed in the amount of loaded sericin extract and added water, the data obtained from the DSC analyses indicated that the differences in the thermal behavior of the several bioorigami films arised mainly from the protein added, and also that incorporation of sericin at very high levels does compromise the stability of the bioorigami film for the intended use. The presence of protein in the bioorigami films promoted a slight shift of the endothermic event next to $122.76^{\circ} \mathrm{C}$ in the plain bioorigami, and increasing loadings of sericin in the bioorigami film also led to decreasing variations in the melting enthalpies (viz., $\Delta \Delta \mathrm{H}$ ) as can be seen in Table 6 which is in clear agreement with the increasing amounts of loaded sericin and concomitant decreasing amounts of water in the bioorigami films.

Unfortunately, for very high amounts of sericin in the bioorigami film, thermal stability of the film decreases (which can be concluded by the high decrease in the temperature peak, associated with the high decrease in the melting enthalpy value). The addition (impregnation) of crude sericin extract promoted a slight increase in the melting temperature peak at lower levels of addition (Figure 3), and a higher decrease in the melting temperature peak at higher levels of addition (Figure 3), denoting a decreased stability of the bioorigami film at higher loadings with sericin. The decrease in the melting temperature verified at higher loadings of the bioorigami with crude sericin extract might be due to amorphization of the system. The results obtained from the DSC thermal analyses carried out with both sericin-loaded and unloaded bioorigami films

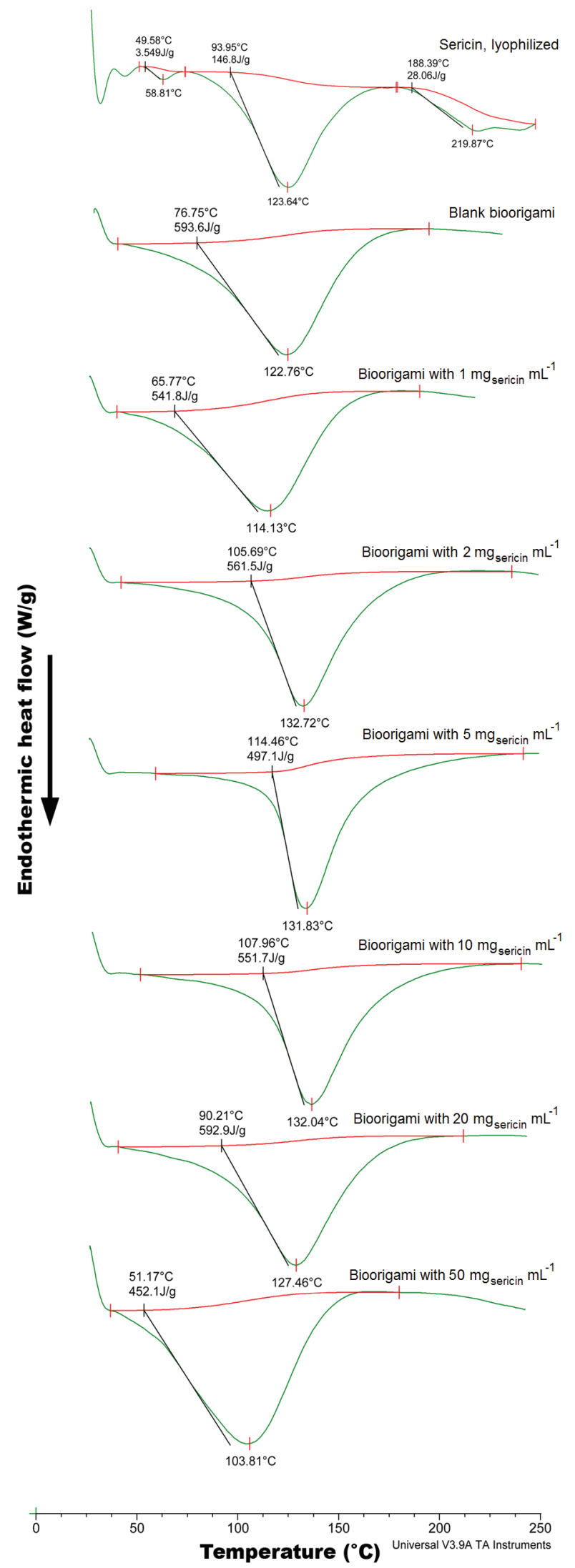

Figure 3. Differential scanning calorimetry thermograms of lyophilized sericin extract and bioorigami films loaded with variable amounts of sericin. 
Table 6. Values of endothermic events by differential scanning calorimetry (DSC)

\begin{tabular}{|c|c|c|c|}
\hline $\begin{array}{l}\text { Bioorigami film with diferents amoung } \\
\text { of sericin }\end{array}$ & Temperature $/{ }^{\circ} \mathrm{C}$ & $\begin{array}{l}\text { Variation in endothermic event } \\
\text { close at } 122.76{ }^{\circ} \mathrm{C} /{ }^{\circ} \mathrm{C} \\
\end{array}$ & $\begin{array}{l}\text { Variations in the melting } \\
\text { enthalpies }(\Delta \Delta \mathrm{H}) /\left(\mathrm{J} \mathrm{g}^{-1}\right)\end{array}$ \\
\hline Plain bioorigami film & 122.76 & - & - \\
\hline Bioorigami film with $1 \mathrm{mg}_{\text {sericin }} \mathrm{mL}_{\text {film }}{ }^{-1}$ & 114.13 & -8.63 & -51.8 \\
\hline Bioorigami film with $2 \mathrm{mg}_{\text {sericin }} \mathrm{mL}_{\text {film }}{ }^{-1}$ & 132.72 & +9.96 & -32.1 \\
\hline Bioorigami film with $5 \mathrm{mg}_{\text {sericin }} \mathrm{mL}_{\text {film }}{ }^{-1}$ & 131.83 & +9.07 & -96.5 \\
\hline Bioorigami film with $10 \mathrm{mg}_{\text {sericin }} \mathrm{mL}_{\text {film }}{ }^{-1}$ & 132.04 & +9.28 & -41.9 \\
\hline Bioorigami film with $20 \mathrm{mg}_{\text {sericin }} \mathrm{mL}_{\text {film }}^{-1}$ & 127.46 & +4.70 & -0.7 \\
\hline Bioorigami film with $50 \mathrm{mg}_{\text {sericin }} \mathrm{mL}_{\text {film }}{ }^{-1}$ & 103.81 & -18.95 & -141.5 \\
\hline
\end{tabular}

(Figure 3) are in close agreement with those obtained from $\mathrm{X}$-ray diffraction studies (Figure 4), since as can be seen from inspection of the DSC thermograms, impregnation of the bioorigami films with crude sericin extract led to a decreased crystallinity. Remarkably, the thermal events depicted in Figure 3 and the X-ray diffractograms depicted in Figure 4 denote a clear transition from a (more) crystalline state of the blank bioorigami film (Figure 4, gray curve) to a (more) amorphous counterpart (Figure 4, bioorigami film loaded with the highest amount of crude sericin extract, light pink curve).

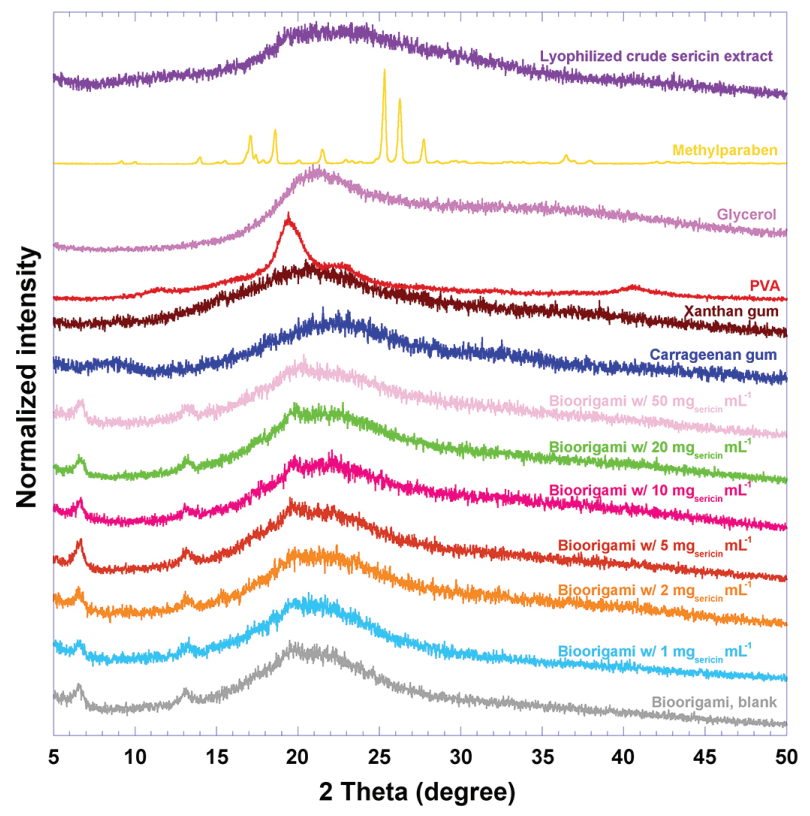

Figure 4. X-ray diffractograms (XRD) normalized of lyophilized sericin extract (purple curve), methylparaben (yellow curve), glycerol (pink curve), PVA (red curve), xanthan gum (dark brown curve), carrageenan gum (dark blue curve), blank bioorigami film (gray line), bioorigami film with 1, 2, 5, 10, 20, $50 \mathrm{mg} \mathrm{mL}^{-1}$ sericin (light blue, orange, light brown, dark pink, green, light pink curves, respectively).

\section{$\mathrm{XRD}$ analyses}

The results obtained from the XRD analyses performed to both the bioorigami films and their isolated constituents are displayed in Figure 4 in the normalized form allowing to observe generalized amorphous behavior with two small peaks of crystallinity for the bioorigami films.

Normalization of intensity in all diffractograms was performed by dividing the intensity values by the maximum intensity value in each diffractogram (Figure 4), thus allowing a better comparison between the X-ray diffractograms of all samples assayed. The diffractograms of the sericin-loaded and unloaded bioorigami films shared a common feature, exhibiting a wide noisy band (less defined and shallow) between $16.00 \leq 2 \theta \leq 29.00$ with more welldefined (crystallinity) peaks in the regions of $6.00 \leq 2 \theta \leq$ 7.00 and $12.00 \leq 2 \theta \leq 14.00$, indicating the dominance of amorphous material in the bioorigami films, ${ }^{30}$ clearly imparted by sericin, xanthan gum and carrageenan gum. The two small peaks of crystallinity in the bioorigami films most likely originated from the methylparaben and PVA utilized in the formulation. When comparing the diffractograms of the unloaded bioorigami film (gray curve in Figure 4) and the bioorigami film loaded with the highest amount of sericin (see light pink curve in Figure 4), a widening and flattening of the broad noisy band between $16.00 \leq 2 \theta \leq 29.00$ is most noticed, due to amorphization of the system to a higher extent promoted by the high sericin payload. These results corroborate the results obtained via FESEM, which indicated the formation of an essentially amorphous film. The decisive advantage of the methods of analysis by X-ray diffraction over other analytical techniques is based on the uniqueness of the diffraction patterns of crystalline substances, on the ability to distinguish between elements and their oxides, and on the possibility of identifying chemical compounds, polymorphic forms and mixed crystals, via non-destructive analyses. Peaks having high intensity and narrow base width are related to crystalline materials while wide base peaks are related to amorphous materials.

Free radical scavenging activity of the bioorigami films integrating variable amounts of sericin

The results obtained for the DPPH radical scavenging 
activity of ascorbic acid and all bioorigami films integrating variable amounts of sericin are displayed in Table 7.

Table 7. Antioxidant activity of the several bioorigami films integrating varying amounts of sericin, as free radical scavenging ability measured via the DPPH methodology

\begin{tabular}{lcc}
\hline $\begin{array}{l}\text { Sericin load in the } \\
\text { bioorigami film / } \\
\left(\mathrm{mg}_{\text {sericin }} \mathrm{mL}_{\text {film }}{ }^{-1}\right)\end{array}$ & $\begin{array}{r}\text { Free (relative) radical scavenging activity } \\
\text { [average }(\mathrm{n}=3) \pm \sigma] / \%\end{array}$ \\
\cline { 2 - 3 } 0 & $96.50 \pm 0.23$ & $0.00 \pm 0.00$ \\
1 & - & $0.00 \pm 0.00$ \\
2 & - & $0.00 \pm 0.00$ \\
5 & - & $0.00 \pm 0.00$ \\
10 & - & $0.00 \pm 0.00$ \\
20 & - & $19.50 \pm 0.00$ \\
50 & - & $24.19 \pm 4.50$ \\
\hline
\end{tabular}

$\mathrm{n}$ : number of experiments; $\sigma$ : standard deviation.

For very low levels of sericin in the bioorigami films no antioxidant activity could be detected and, for those with the highest levels of sericin load, different levels of DPPH radical scavenging activity were observed (Table 7). The bioorigami film integrating the highest load of sericin exhibited the strongest DPPH radical scavenging activity. Ascorbic acid at $0.5 \mathrm{mg} \mathrm{mL} \mathrm{mL}^{-1}$ exhibited free radical scavenging power of $96.5 \%$. Hence, the results obtained in the present research effort suggest that both bioorigami films integrating 20 and $50 \mathrm{mg}_{\text {sericin }} \mathrm{mL}_{\text {film }}{ }^{-1}$ are capable of sequestering the free radicals (although at different extensions) and prevent the initiation of free radicals by stabilizing them to participate in any deleterious reactions. These results are in clear agreement with the results previously published by Rocha et $a l .{ }^{14}$ and Rangi and Jajpura. ${ }^{31}$ Different concentrations of silk sericin in the bioorigami films allowed different abilities to quench the DPPH radicals. It was observed that the bioorigami films with 20 and $50 \mathrm{mg}_{\text {sericin }} \mathrm{mL}_{\text {film }}{ }^{-1}$ scavenged $19.50 \pm 0.00$ and $24.19 \pm 4.50 \%$ of DPPH radicals, respectively (Table 7 ). Fan et $a l .{ }^{32}$ refer in their work that the functional groups present in the aminoacid moieties cysteine, tyrosine and hystidine that compose the primary structure of sericin reduce and decolorize DPPH via their hydrogen-donating ability. Hence, it is not surprising to conclude that the silk sericin that was released form the bioorigami films contains electron donors that react with free radicals to convert them to more stable products and terminate the radical chain reaction.

The DPPH method has been widely applied for estimating antioxidant activity and not requiring comparison standard agents. The method offers advantages of being rapid, simple and inexpensive and provides first-hand information on the overall antioxidant capacity of the test system. The ascorbic acid was used for comparison only because of its strength with free radical sequestered. ${ }^{33}$

\section{Mechanical resistance of the bioorigami films}

Evaluation of the mechanical properties of the bioorigami films produced without sericin, according to the factorial design depicted in Table 1 and composition displayed in Table 2, encompassed resistance to perforation, resistance to traction and resilience (Figure 5).
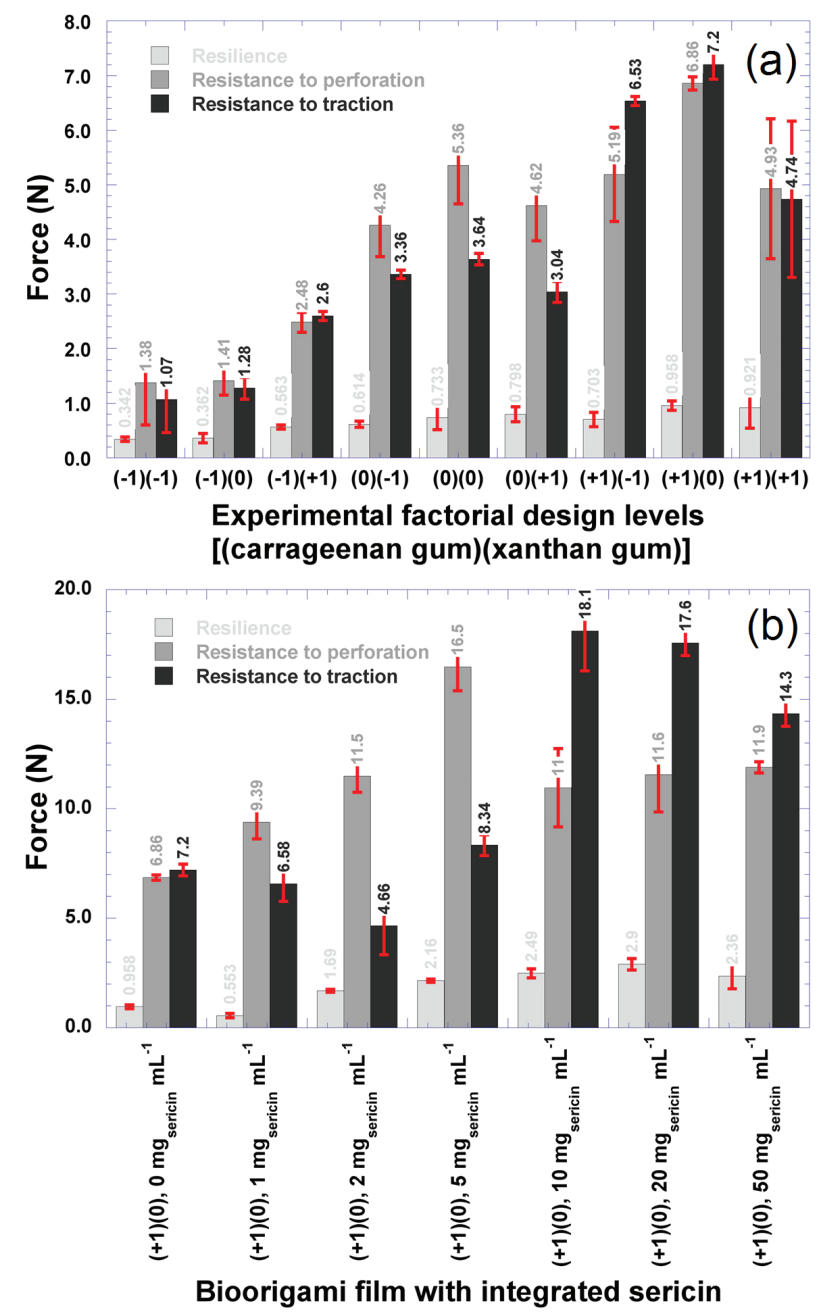

Figure 5. Results gathered from the mechanical resistance tests performed to the (a) plain bioorigami films evolved from the experimental factorial design, and (b) bioorigami films produced with varying loads of sericin having as base the levels $(+1)$ of carrageenan and (0) of xanthan gums.

According to the results displayed in Figure 5a, the best results produced in terms of resistance to perforation, resistance to traction and resilience were obtained for the levels $(+1)$ of carrageenan gum and (0) of xanthan gum. The ability of the bioorigami film to spring back 
into shape following deformation caused by straining was an especially important attribute, since its elasticity (i.e., its resilience) is an important characteristic for skin applications. Hence, this set of biopolysaccharide levels was followed for the production of bioorigami films loaded with sericin (Figure 5b). The mechanical properties of the bioorigami films are mainly related with the biopolymer's ability to form bonds in polymer chains, difficulting their separation when subject to mechanical forces. ${ }^{34}$ The plasticizer used (glycerol, in this case) also has an influence on these properties..$^{35}$ The results produced during evaluation of the mechanical resistance of the bioorigami films with different sericin loads, with respect to perforation, traction and resilience, are displayed in Figure 5b. From inspection of the data displayed in Figure $5 b$, increasing sericin loads in the bioorigami film produced increasing resistance to perforation and resilience and decreasing resistance to traction for sericin loads up to $2 \mathrm{mg}_{\text {sericin }} \mathrm{mL}_{\text {film }}{ }^{-1}$. For higher sericin loads in the bioorigami film, this trend was somehow inverted, and the bioorigami film loaded with $10 \mathrm{mg}_{\text {sericin }} \mathrm{mL}_{\text {film }}{ }^{-1}$ produced the best results in terms of resilience, resistance to perforation and resistance to traction, when compared with all other bioorigami films and also with its counterpart without sericin. Hence, it may be concluded that the presence of sericin in higher amounts improved the viscoelastic characteristics of deformation and molecular relaxation (viz., return of the bioorigami film from strained conditions back into equilibrium). The bioorigami film produced with the highest sericin load (Figure 5b) presented a decrease in resilience and a marked decrease in resistance to traction. The major goal of the research work undertaken was to develop a bioorigami film based on biopolysaccharides and impregnated with silk sericin, suitable for application in skin regeneration. In our perspective, the bioorigami film applied directly to a damaged skin should not strongly adhere, allowing regeneration and re-epithelialization of damaged skin. Thus, perforation, traction and resillience were the mechanical resistance parameters evaluated, whereas adhesiveness or bioadhesiveness were not at all considered important in the research work developed. The optimized bioorigami film is intended to be applied to a damaged skin and maintained in place by a bandage, and not to stick or adhere to the wounded skin. Our perspective is supported by literature references. ${ }^{36,37}$ The bioorigami film is also intended to help in maintaining a suitable microclimate on the damaged skin surface, of utmost importance for the biosynthetic reactions necessary for cellular activities. Skin dressings allow the creation of a moist and warm environment beneath the bioorigami film, thus bringing benefits to the regeneration process. ${ }^{38}$

\section{Transdermal permeation of sericin from bioorigami films}

The results obtained from the transdermal permeation of sericin from the different bioorigami films are displayed in Figure 6.
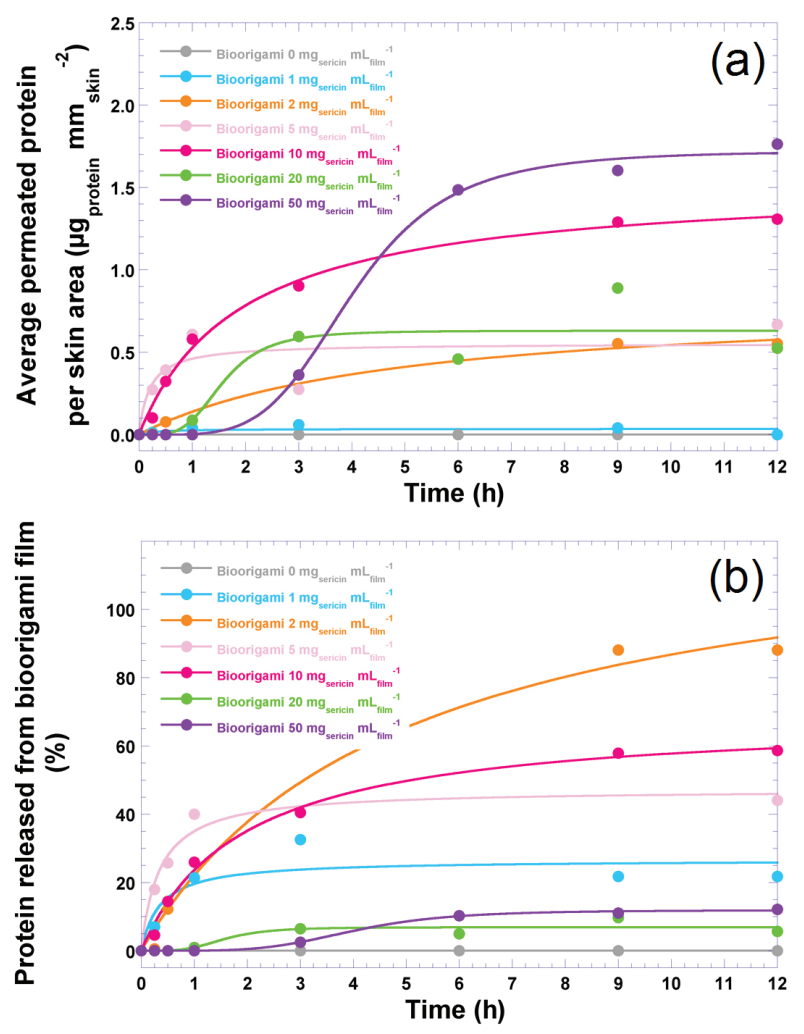

Figure 6. Results gathered from transdermal permeation studies $(n=3)$, as (a) average permeated protein per skin area, and (b) percentage of protein released from bioorigami films relative to the amount of sericin loaded in the films, during a $12 \mathrm{~h}$ timeframe assay. Solid lines represent nonlinear fittings performed to the data, viz., hyperbolic for those bioorigami films loaded with sericin amounts between 0 and $10 \mathrm{mg}_{\text {sericin }} \mathrm{mL}_{\text {film }}{ }^{-1}$, and Gompertz function for those bioorigami films loaded with sericin amounts between 20 and $50 \mathrm{mg}_{\text {sericin }} \mathrm{mL}_{\text {film }}{ }^{-1}$.

As can be observed from inspection of Figure 6a, increasing loadings of sericin in the bioorigami film led to increased average permeated protein per skin area. Performing non-linear (hyperbolic, $y=\frac{\mathrm{m}_{1} x}{\mathrm{~m}_{2}+x}$ ) fittings to the results obtained from transdermal permeation of protein from bioorigami films loaded with $1,2,5$ and $10 \mathrm{mg}_{\text {sericin }} \mathrm{mL}_{\text {film }}{ }^{-1}$, one obtained the maximum average protein permeated per skin area (parameter $\mathrm{m}_{1}$, Table 8 ) and the time required to achieve half of the maximum average protein permeated per skin area (parameter $\mathrm{m}_{2}$, Table 8), with excellent correlation coefficients. Regarding higher sericin loadings, at 20 and $50 \mathrm{mg}_{\text {sericin }} \mathrm{mL}_{\text {film }}{ }^{-1}$, the sigmoidal trend of the protein permeation data was best described by a non-linear fit of the Gompertz function $\left(y=\mathrm{m}_{1} \mathrm{e}^{-\mathrm{m}_{2} \mathrm{e}^{-\mathrm{m}_{3} x}}\right.$, 
Figure 6a and Table 8), allowing to obtain the value of the asymptote $\left(\mathrm{m}_{1}\right.$, i.e., the maximum attainable permeated protein per skin area, see Table 8), the displacement of the data trend along the timeframe studied (viz., $\mathrm{m}_{2}$, Table 8) and the data growth rate (viz., $\mathrm{m}_{3}$, Table 8), with excellent correlation coefficients. The Gompertz function is a sigmoid function, where growth is slowest at both start (where protein concentration was initially high, so skin uptake was slow) and end (due to slowing of protein permeation as saturation was reached in the skin) of a given time period.

As can be observed from inspection of Figure $6 \mathrm{a}$ and the data in Table 8, the bioorigami film with the highest sericin load allowed the highest average permeated protein per skin area, viz., $1.7022 \mu \mathrm{g}_{\text {protein }} \mathrm{mm}^{2} \mathrm{skin}^{-1}$. However, this highest amount of permeated protein from bioorigami film with the highest load of sericin translated only to ca. $11.73 \%$ of the total protein content in this bioorigami film after $12 \mathrm{~h}$ (Figure $6 \mathrm{~b}$ and Table 9).
Clearly this is not at all an ideal situation in a real skin application, since patching this bioorigami in the skin would lead to a waste of protein paramounting to ca. $88.27 \%$ of the protein load in the film, due to saturating conditions in the skin. On the other hand, the bioorigami film loaded with $2 \mathrm{mg}_{\text {protein }} \mathrm{mL}_{\text {film }}{ }^{-1}$ allowed the release of virtually all protein into the skin during a 12-h timeframe, which translated into $0.807 \mu \mathrm{g}_{\text {protein }} \mathrm{mm}^{2}$ skin $^{-1}$ (Table 8). In a real skin application, the bioorigami film loaded with $2 \mathrm{mg}_{\text {protein }} \mathrm{mL}_{\text {film }}^{-1}$ would advocate an ideal situation, but the low sericin load would make it unpracticable. On the other hand, and also considering its mechanical properties as discussed before, the bioorigami film loaded with $10 \mathrm{mg}_{\text {protein }} \mathrm{mL}_{\text {film }}{ }^{-1}$ would be ideal since in a 12-h timeframe (considered adequate) ca. $50 \%$ of all the bioactive protein in the bioorigami film would be released into the skin. On the contrary, the bioorigami films loaded with either 20 or $50 \mathrm{mg}_{\text {protein }} \mathrm{mL}_{\text {film }}{ }^{-1}$ would not allow release of more protein into the skin even for longer timeframes (Table 9).

Table 8. Results obtained from the non-linear fittings performed to the average permeated protein per skin area as a function of permeation time, for the several bioorigami films integrating varying amounts of sericin

\begin{tabular}{|c|c|c|c|c|c|c|}
\hline \multirow{2}{*}{$\begin{array}{l}\text { Sericin load in the } \\
\text { bioorigami film / } \\
\left(\mathrm{mg}_{\text {sericin }} \mathrm{mL}_{\text {film }}{ }^{-1}\right)\end{array}$} & \multicolumn{2}{|c|}{ Hyperbolic function: $y=\frac{\mathrm{m}_{1} x}{\mathrm{~m}_{2}+x}$} & \multicolumn{3}{|c|}{ Gompertz function: $y=\mathrm{m}_{1} \mathrm{e}^{-\mathrm{m}_{2} \mathrm{c}^{-\mathrm{m}_{3} x}}$} & \multirow[t]{2}{*}{$\mathrm{r}$} \\
\hline & $\mathrm{m}_{1} /\left(\mu \mathrm{g}\right.$ protein $\left.\mathrm{mm}^{2} \mathrm{skin}^{-1}\right)$ & $\mathrm{m}_{2} / \mathrm{h}$ & $\mathrm{m}_{1} /\left(\mu \mathrm{g}\right.$ protein $\left.\mathrm{mm}^{2} \mathrm{skin}^{-1}\right)$ & $\mathrm{m}_{2} / \mathrm{h}$ & $\mathrm{m}_{3} / \mathrm{h}$ & \\
\hline 1 & 0.03400 & 0.35955 & - & - & - & 0.52251 \\
\hline 2 & 0.80669 & 4.83650 & - & - & - & 0.99616 \\
\hline 5 & 0.55243 & 0.20255 & - & - & - & 0.82172 \\
\hline 10 & 1.53480 & 1.92380 & - & - & - & 0.99699 \\
\hline 20 & - & - & 0.62395 & 12.748 & 1.86340 & 0.93200 \\
\hline 50 & - & - & 1.70220 & 16.362 & 0.78679 & 0.99892 \\
\hline
\end{tabular}

Hyperbolic function: $\mathrm{m}_{1}$ : maximum average protein permeated per skin area; $\mathrm{m}_{2}$ : time required to achieve half of the maximum average protein permeated per skin area; Gompertz function: $\mathrm{m}_{1}$ : asymptote, i.e., the maximum attainable permeated protein per skin area; $\mathrm{m}_{2}$ : displacement of the data trend along the timeframe studied; $\mathrm{m}_{3}$ : data growth. $\mathrm{r}$ : correlation coefficient.

Table 9. Results obtained from the non-linear fittings performed to the average protein released from bioorigami film as a function of permeation time, for the several bioorigami films integrating varying amounts of sericin

\begin{tabular}{|c|c|c|c|c|c|c|}
\hline \multirow{2}{*}{$\begin{array}{l}\text { Sericin load in the } \\
\text { bioorigami film / } \\
\left(\mathrm{mg}_{\text {sericin }} \mathrm{mL}_{\text {film }}^{-1}\right)\end{array}$} & \multicolumn{2}{|c|}{ Hyperbolic function: $y=\frac{\mathrm{m}_{1} x}{\mathrm{~m}_{2}+x}$} & \multicolumn{3}{|c|}{ Gompertz function: $y=\mathrm{m}_{1} \mathrm{e}^{-\mathrm{m}_{2} \mathrm{e}^{-\mathrm{m}_{3} x}}$} & \multirow{2}{*}{$\mathrm{r}$} \\
\hline & $\mathrm{m}_{1} /\left(\mu \mathrm{g}\right.$ protein $\left.\mathrm{mm}^{2} \mathrm{skin}^{-1}\right)$ & $\mathrm{m}_{2} / \mathrm{h}$ & $\mathrm{m}_{1} /\left(\mu \mathrm{g}\right.$ protein $\left.\mathrm{mm}^{2} \mathrm{skin}^{-1}\right)$ & $\mathrm{m}_{2} / \mathrm{h}$ & $\mathrm{m}_{3} / \mathrm{h}$ & \\
\hline 1 & 26.589 & 0.35864 & - & - & - & 0.90344 \\
\hline 2 & 128.68 & 4.83850 & - & - & - & 0.99616 \\
\hline 5 & 47.225 & 0.34991 & - & - & - & 0.98566 \\
\hline 10 & 68.840 & 1.92380 & - & - & - & 0.99699 \\
\hline 20 & - & - & 6.81460 & 12.7470 & 1.86330 & 0.93200 \\
\hline 50 & - & - & 11.7270 & 16.3630 & 0.78680 & 0.99892 \\
\hline
\end{tabular}

Hyperbolic function: $\mathrm{m}_{1}$ : maximum average protein permeated per skin area; $\mathrm{m}_{2}$ : time required to achieve half of the maximum average protein permeated per skin area; Gompertz function: $\mathrm{m}_{1}$ : asymptote, i.e., the maximum attainable permeated protein per skin area; $\mathrm{m}_{2}$ : displacement of the data trend along the timeframe studied; $\mathrm{m}_{3}$ : data growth. $\mathrm{r}$ : correlation coefficient. 
Mathematical modelling of sericin release from bioorigami films

To shed light on the release profile of protein (sericin) from the bioorigami films, and because after the $12 \mathrm{~h}$ timeframe of assays the amount of protein released (that effectively permeated through the skin membrane into the receiving phosphate buffer) reached a plateau, one applied the mathematical models of first order $\left(\ln \mathrm{Q}_{t}=\ln \mathrm{Q}_{0}+\mathrm{k}_{1} \times \mathrm{t}\right.$, where $Q_{t}$ is the amount of protein released at time $t, Q_{0}$ is the initial amount of protein in dosage form, $\mathrm{k}_{1}$ is a release rate constant, and $t$ is time), Higuchi $\left(Q_{t}=k_{H} \sqrt{t}\right.$, where $Q_{t}$ is the amount of protein released at time $t, k_{H}$ is the Higuchi constant and $t$ is time) and Korsmeyer-Peppas $\left(Q_{t} / Q_{\infty}=k_{K P} t^{n}\right.$, where $Q_{t}$ is the amount of protein released at time $t, Q_{\infty}$ is the total amount of protein permeated when the dosage form (bioorigami film) is exhausted, $\mathrm{k}_{\mathrm{KP}}$ is the Korsmeyer-Peppas kinetic constant, $\mathrm{n}$ is the diffusion or release exponent, ant $\mathrm{t}$ is time) to protein drug release (permeation) data. The protein determinations undertaken clearly showed (Figures 6a and 6b) that the protein release (permeation) profile reached increasing plateaus with increasing loads of sericin in the bioorigami films. In fact, for sericin loadings of 2 and $50 \mathrm{mg}_{\text {sericin }} \mathrm{mL}_{\text {film }}{ }^{-1}$, protein release from the bioorigami films did not occur by diffusion but by erosion of the biopolymeric matrix instead (Figure 7b), whereas for sericin loadings of 1, 10 and $20 \mathrm{mg}_{\text {sericin }} \mathrm{mL}_{\text {film }}{ }^{-1}$ protein release from the bioorigami films did occur by diffusion (Figure 7b). The fittings performed clearly show a poorer correlation coefficient (r) for both first-order and Higuchi models and a much better $r$ for the Korsmeyer-Peppas model. Additionally, the diffusion or release exponent (n) in the Korsmeyer-Peppas model produced by fitting the model to the protein release data (Figures $7 \mathrm{a}$ and $7 \mathrm{~b}$ ) was $\mathrm{n}=0.55673\left(1 \mathrm{mg}_{\text {sericin }} \mathrm{mL}_{\text {film }}{ }^{-1}\right)$, $\mathrm{n}=1.19010\left(2 \mathrm{mg}_{\text {sericin }} \mathrm{mL}_{\text {film }}{ }^{-1}\right), \mathrm{n}=0.20758$ $\left(5 \mathrm{mg}_{\text {sericin }} \mathrm{mL}_{\text {film }}{ }^{-1}\right), \mathrm{n}=0.58699\left(10 \mathrm{mg}_{\text {sericin }} \mathrm{mL}_{\text {film }}{ }^{-1}\right)$, $\mathrm{n}=0.75754\left(20 \mathrm{mg}_{\text {sericin }} \mathrm{mL}_{\text {film }}{ }^{-1}\right)$ and $\mathrm{n}=1.15200$ $\left(50 \mathrm{mg}_{\text {sericin }} \mathrm{mL}_{\text {film }}{ }^{-1}\right)$ (in the Korsmeyer-Peppas drug release model, $\mathrm{n}=0.45$ suggests Fickian diffusion, $0.45<\mathrm{n}<0.89$ suggests anomalous diffusion or non-Fickian diffusion, and $\mathrm{n} \geq 0.89$ suggests erosion of the polymeric chain), which clearly suggests that protein release from the bioorigami films loaded with 2 and $50 \mathrm{mg}_{\text {sericin }} \mathrm{mL}_{\text {film }}{ }^{-1}$ did not occur by diffusion but by erosion of the biopolymeric matrix instead (Figure 7b), whereas for sericin loadings of 1, 10 and $20 \mathrm{mg}_{\text {sericin }} \mathrm{mL}_{\text {film }}{ }^{-1}$ protein release from the bioorigami films did occur by anomalous diffusion or non-Fickian diffusion (Figure 7b).

The linear fittings performed to the transformed protein permeation (release) data using the Korsmeyer-Peppas
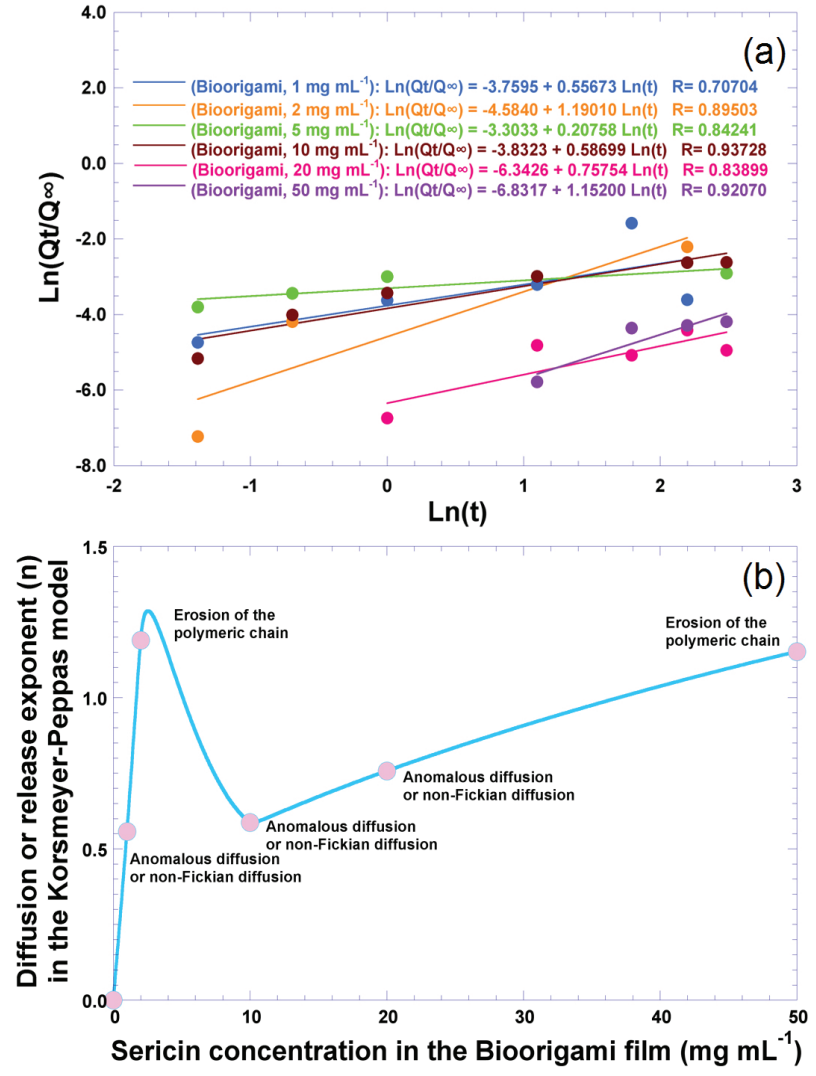

Figure 7. Results obtained from the mathematical modelling of the sericin release assays from the sericin-loaded bioorigami films during a $12 \mathrm{~h}$ timeframe assay. (a) Linear fittings performed to transformed experimental data, using the linearized Korsmeyer-Peppas model; (b) diffusion or release exponent (n) in the Korsmeyer-Peppas model as a function of sericin load in the bioorigami film allowing observation of the change in the sericin release pattern.

model (Figure 7a) allow to see that nearly perfect fittings were produced, further supporting the conclusion that protein release from the bioorigami films occurred by anomalous diffusion or non-Fickian diffusion for very low and intermediate sericin loadings, and by erosion of the biopolymeric matrix for low and very high sericin loadings (Figure 7b). Although a slower bioactive protein liberation is intended for real skin applications, where the bioorigami film is intended for application in a skin where the normal exudation produced is not as abundant as the conditions implemented in the laboratory, erosion of the bioorigami film with concomitant release of protein should happen to a much lower extent.

\section{XRT analyses}

The optimized bioorigami film developed may be considered a natural polymer composite exhibiting a very special porous microstructure that enables the film to possess outstanding mechanical properties. From the tomographic analyses via $\mathrm{X}$-ray transmission performed 
to a square section of the bioorigami film loaded with $10 \mathrm{mg}_{\text {sericin }} \mathrm{mL}_{\text {film }}^{-1}$ (Figure 8), a homogeneous surface can be observed.

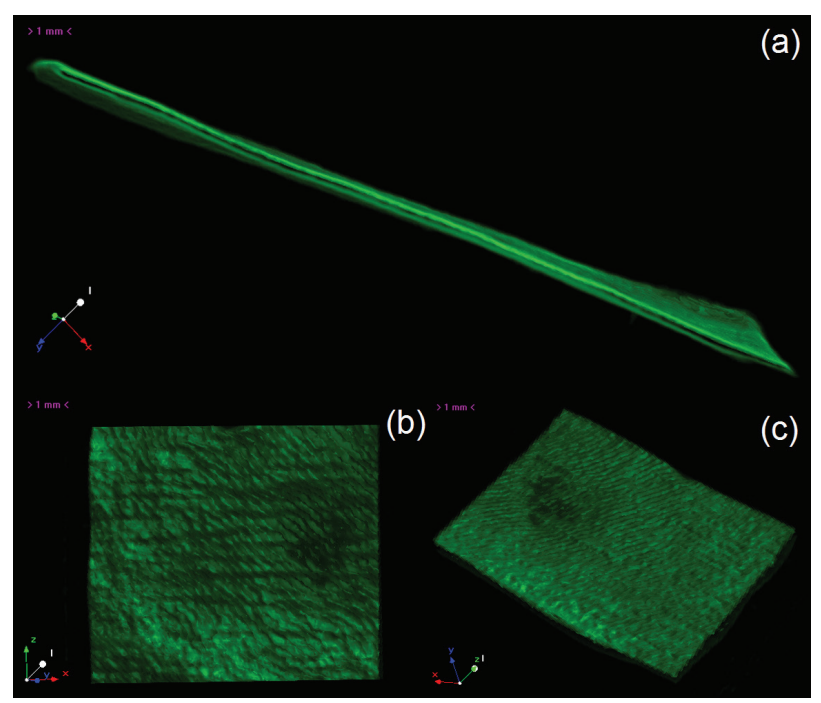

Figure 8. Images obtained by tomographic analyses via X-ray transmission of the bioorigami film loaded with $10 \mathrm{mg}_{\text {sericin }} \mathrm{mL}_{\text {film }}{ }^{-1}$, being (a) a slant profile image of the bioorigami film, (b) image perpendicular to the surface of the bioorigami film, and (c) leaning surface view of the bioorigami film. Three-dimensional image slices were gathered using an operating voltage set at $29 \mathrm{kV}$ and electric current with $415 \mu \mathrm{A}$.

Due to absorbing more radiation, because of its higher atomic density, the biopolysaccharide matrix network (in green in Figure 8) is in greater evidence, whereas void spaces appear in black. These results are in close agreement with those obtained by infrared spectrophotometry (Figure 1) which indicated that sericin probably did not engage in any chemical bonding with the biopolymeric matrix. This is clearly an important and positive data, since by not engaging in any chemical bonding with the biopolymeric matrix, sericin becomes readily available and maintains its antioxidant activity. The porosity analysis of the bioorigami film loaded with $10 \mathrm{mg}_{\text {sericin }} \mathrm{mL}_{\text {film }}{ }^{-1}$ can be found in Table 10, resulting from 2D and 3D morphological analyses.

Anisotropy is the property of being directionally dependent, as opposed to isotropy, which implies identical properties in all directions. Anisotropy may be defined as a difference, when measured along different axes, in the mechanical or physical properties of a material. The degree of anisotropy, calculated as Degree of anisotropy $=1-\left(\right.$ Eigenvalue $_{\min } /$ Eigenvalue $\left._{\max }\right)$, is 0 for total isotropy and 1 for total anisotropy. Hence, as can be seen from inspection of the data in Table 10, the degree of anisotropy is 0.75480 for the bioorigami film loaded with $10 \mathrm{mg}_{\text {sericin }} \mathrm{mL}_{\text {film }}{ }^{-1}$, a value that is closer to anisotropy than to isotropy in the aforementioned scale. When analyzing the structure of the bioorigami film loaded with $10 \mathrm{mg}_{\text {sericin }} \mathrm{mL}_{\text {film }}{ }^{-1}$, one finds that it has an open porosity of $50.61 \%$ and an equal value of total porosity (Table 10). Additionally, the mean fragmentation index (Table 10) gives an index of connectivity and calculates an index of relative convexity or concavity of the total object surface, on the principle that concavity indicates connectivity (and the presence of "nodes"), and convexity indicates isolated disconnected structures (struts). Lower fragmentation indexes mean better connected lattices while higher fragmentation indexes means a more disconnected structure. Scarce enclosed cavities and concave surfaces can push the fragmentation index to (large) positive values, which was in fact determined in the analyses performed (Table 10). These results are quite important since sericin was homogeneously dispersed throughout the biopolymeric structure of the bioorigami film during the polymerization process, the bioorigami can be applied with either of its surfaces towards the skin. More data from 2D and 3D morphological analyses are available in Supplementary Information section.

Table 10. Results obtained from the tomographic analyses via X-ray transmission performed to the bioorigami films integrating variable amounts of sericin from Bombyx mori cocoons

\begin{tabular}{lcc}
\hline \multirow{2}{*}{ Parameter } & \multicolumn{2}{c}{ Bioorigami film loaded with $10 \mathrm{mg}_{\text {sericin }} \mathrm{mL}_{\text {film }}{ }^{-1}$} \\
\cline { 2 - 3 } Degree of anisotropy (DA) & Bi-dimensional (2D) morphological analysis & Three-dimensional (3D) morphological analysis \\
Eigenvalue 1 & - & $4.07826(0.75480)$ \\
Eigenvalue 2 & - & 0.02233 \\
Eigenvalue 3 & - & 0.06913 \\
Mean fragmentation index (Fr.I) $/ \mathrm{mm}^{-1}$ & 11.9519 & 0.09109 \\
Volume of open pore space (Po.V(op)) $/ \mathrm{mm}^{3}$ & - & 15.3358 \\
Open porosity (Po(op)) $/ \%$ & - & 0.03581 \\
Total volume of pore space (Po.V(tot)) $/ \mathrm{mm}^{3}$ & - & 50.6068 \\
Total porosity (Po(tot)) $/ \%$ & - & 0.035810 \\
\hline
\end{tabular}




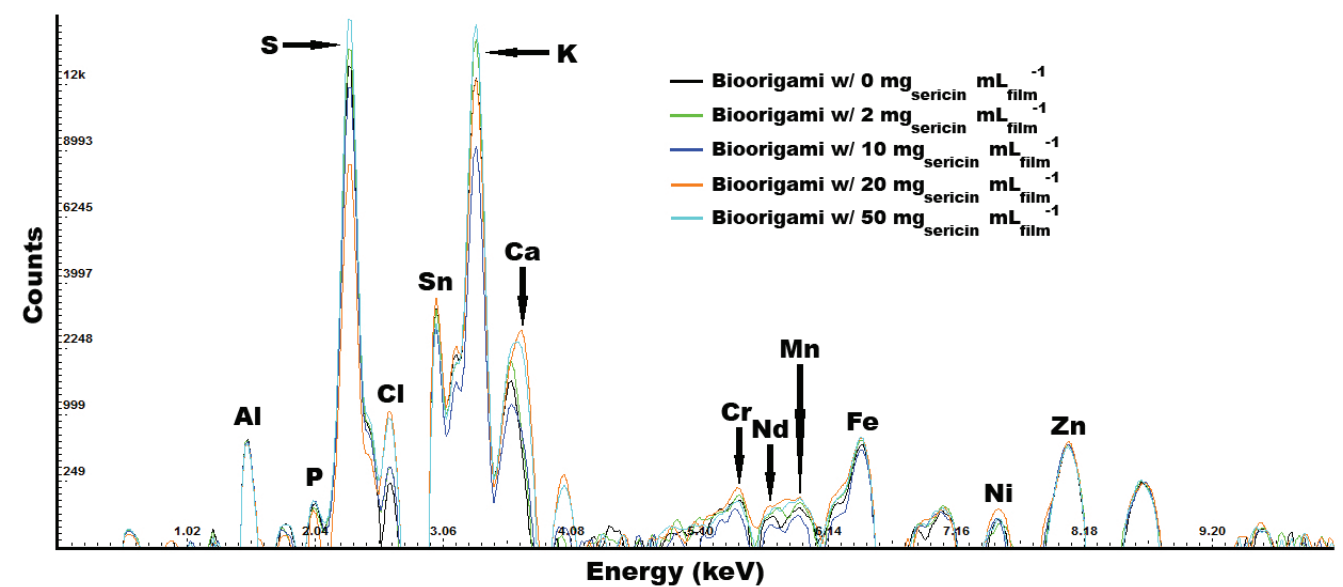

Figure 9. EDXRF spectra of selected bioorigami films loaded with variable amounts of sericin. The $y$-axis represents the number of characteristic X-ray counts that reached the detector, while the $x$-axis represents the energy of the characteristic X-rays.

\section{EDXRF analyses}

Figure 9 shows the typical X-ray fluorescence spectra of several bioorigami films produced with variable amounts of sericin from Bombyx mori cocoons. The major chemical elements found are pinpointed in Figure 9.

The measured spectra were analyzed with the XRS-FPTM software package provided by Amptek Inc., taking into account both escape peaks and sum peaks, and representing the background with a polynomial function. The same elements were found in all bioorigami films, but in bioorigami films loaded with higher amounts of sericin (Figure 9), one found larger amounts of $\mathrm{Ca}, \mathrm{S}$ and $\mathrm{K}$ and trace amounts of $\mathrm{P}, \mathrm{Cr}, \mathrm{Nd}, \mathrm{Mn}$ and $\mathrm{Ni}$, results that are consistent and in clear agreement with results published elsewhere ${ }^{14}$ for crude sericin extracts from Bombyx mori cocoons.

Structural microanalysis of bioorigami films integrating sericin, via DESEM analyses

The DESEM images of both the surface and fracture cross-section of the bioorigami films loaded with variable amounts of sericin allows observing a rugged surface with generalized absence of cracks as can be seen in Supplementary Information section.

Probably due to the process involved in preparation of the samples prior to sputter coating with colloidal Au, fixation of the films in the carbon supports by stretching them might have produced the microscopic cracks. Nevertheless, to the selected bioorigami films, a uniform morphology could be observed. The fractured cross-section of the bioorigami films exhibit a highly homogeneous matrix of the biopolymeric structures, which facilitate sericin release upon contact of the film with damaged skin.

\section{Conclusions}

In the research effort just described, development and optimization of a bioorigami film concept loaded with variable amounts of sericin from Bombyx mori cocoons was pursued, aiming at antioxidant and regenerative topical applications. The bioorigami films developed displayed a good characteristic in relation to the release of the active antioxidant moiety, verified through transdermal permeation studies and kinetics associated with the sericin release process, and since release of sericin from the biopolysaccharide matrix of the bioorigami film occurred by non-Fickian diffusion for sericin loads up to $20 \mathrm{mg}_{\text {sericin }} \mathrm{mL}_{\text {film }}{ }^{-1}$, it can be utilized in the occlusive regeneration of wound damages for long periods of time. The bioorigami films loaded with crude sericin extracts from Bombyx mori cocoons were found to be suitable for biopharmacy. The results suggest potential for use in biopharmaceutical application, specifically, as material for use in hydrogels.

\section{Supplementary Information}

Supplementary information (DESEM images of both the surface and fracture cross-section of the bioorigami films and the data from 2D and 3D morphological analyses) is available free of charge at http://jbcs.sbq.org.br as PDF file.

\section{Acknowledgments}

Project funding by Fundação de Amparo à Pesquisa do Estado de São Paulo (FAPESP, São Paulo, Brazil; Refs. No. 2016/08884-3 (Project PneumoPhageColor) and 2016/12234-4 (Project TransAppIL)), and a BPE 
fellowship granted by FAPESP to V. M. B. (FAPESP Ref. No. 2018/05522-9 (Project PsaPhageKill)) is hereby gratefully acknowledged. Funding by FAPESP (Ref. No. 2016/16641-3) in the form of an MSc fellowship granted to L. K. H. is hereby gratefully acknowledged. This work also received support from CNPq, National Council for Scientific and Technological Development, Brazil, in the form of Research Productivity (PQ) fellowships granted to V. M. B. (Refs. No. 306113/2014-7 and 308208/2017-0).

\section{References}

1. Andrews, G. P.; Laverty, T. P.; Jones, D. S.; Eur. J. Pharm. Biopharm. 2009, 71, 505.

2. Ganji, F.; Vasheghani-Farahani, S.; Vasheghani-Farahani, E.; Iran. Polym J. 2010, 19, 375.

3. Yan, C.; Pochan, D. J.; Chem Soc. Rev. 2010, 3, 3528.

4. Murphy, D. J.; Sankalia, M. G.; Loughlin, R. G.; Donnelly, R. F.; Jenkins, M. G.; McCarron, P. A.; Int. J. Pharm. 2012, 432, 326.

5. Song, A.; Rane, A. A.; Christman, K. L.; Acta Biomater. 2009 , 8,41 .

6. Liu, Y.; Vrana, N. E.; Cahill, P. A.; McGuinness, G. B.; J. Biomed. Mater. Res., Part B 2009, 90, 492.

7. Hwang, M. R.; Kim, J. O.; Lee, J. H.; Kim, Y. I.; Kim, J. H.; Chang, S. W.; Jin, S. G.; Kim, J. A.; Lyoo, W. S.; Han, S. S.; Ku, S. K.; Yong, C. S.; Choi, H. G.; AAPS PharmSciTech 2010, 11, 1092.

8. Gupta, P.; Vermani, K.; Garg, S.; Drug Discovery Today 2002, $7,569$.

9. Tao, W.; Li, M.; Xie, R.; Macromol. Mater. Eng. 2005, 290, 188.

10. Kunz, R. I.; Brancalhão, R. M. C.; Ribeiro, L. F. C.; Natali, M. R. M.; BioMed Res. Int. 2016, 19, article ID 8175701.

11. Gimenes, M. L.; Silva, V. R.; Vieira, M. G. A.; Silva, M. G. C.; Scheer, A. P.; Int. J. Chem. Eng. Appl. 2014, 5, 266.

12. Chopra, S.; Gulrajani, M. L.; Indian J. Fibre Text. Res. 1994, $19,76$.

13. Cho, K. Y.; Moon, J. Y.; Lee, Y. W.; Lee, K. G.; Yeo, J. H.; Kweon, H. Y.; Kim, K. H.; Cho, S. S.; Int. J. Biol. Macromol. 2003, 32, 36.

14. Rocha, L. K. H.; Favaro, L. I. L.; Rios, A. C.; Silva, E. C.; Silva, W. F.; Stigliani, T. P.; Guilger, M.; Lima, R.; Oliveira Jr., J. M.; Aranha, N.; Tubino, M.; Vila, M. M. D. C.; Balcão, V. M.; Process Biochem. 2017, 61, 163.

15. Robyt, J. F.; White, B. J.; Biochemical Techniques - Theory and Practice; Waveland Press: Chicago, IL, USA, 1990.

16. Balcão, V. M.; Vieira, M. C.; Malcata, F. X.; Biotechnol. Prog. 1996, 12, 164.

17. Wu, J.-H.; Wang, Z.; Xu, S.-Y.; Food Chem. 2007, 103, 1255.
18. Amarowicz, R.; Pegg, R. B.; Rahimi-Moghaddam, P.; Barl, B.; Weil, J. A.; Food Chem. 2004, 84, 551.

19. Caetano, K. S.; Hesse, C. T.; Tondo, E. C.; Flores, S. H.; Cladera-Olivera, F.; J. Food Sci. 2017, 37, e12355.

20. Salerno, C.; Carlucci, A. M.; Bregni, C.; AAPS PharmSciTech 2010, $11,986$.

21. de Oliveira Jr., J. M.; Martins, A. C. G.; AIP Conf. Proc. 2009, 1139, 102.

22. https://www.bruker.com/products/microtomography/micro-ctsoftware/3dsuite.html, accessed in August 12, 2019.

23. Feldkamp, L. A.; Davis, L. C.; Kress, J. W.; J. Opt. Soc. Am. A 1984, 1, 612 .

24. Baker, M. I.; Walsh, S. P.; Schwartz, Z.; Boyan, B. D.; J. Biomed. Mater. Res., Part B 2012, 100, 1451.

25. Gupta, D.; Agrawal, A.; Rangi, A.; Indian J. Fibre Text. Res. 2014, 39, 364.

26. Reis, E. F.; Campos, F. S.; Lage, A. P.; Leite, R. C.; Heneine, L. G.; Vasconcelos, W. L.; Lobato, Z. I. P.; Mansur, H. S.; Mater. Res. 2006, 9, 185.

27. Mehta, P.; Sharma, D.; Dashora, A.; Sahu, D.; Garg, R. K.; Agrawal, P.; Kapoor, D. N.; Innovare J. Life Sci. 2013, 1, 3.

28. Dandurand, J.; Samouillan, V.; Lacoste-Ferre, M. H.; Lacabanne, C.; Bochicchio, B.; Pepe, A.; Pathol. Biol. 2014, $62,100$.

29. Soares, J. P.; Santos, J. E.; Chierice, G. O.; Cavalheiro, E. T. G.; Ecletica Quim. 2004, 29, 53.

30. Young, A. L.; Am. Pharm. Rev. 2012, available at http:// www.americanpharmaceuticalreview.com/FeaturedArticles/38371-Powder-X-ray-Diffraction-and-its-Applicationto-Biotherapeutic-Formulation-development/, accessed in October 2019.

31. Rangi, A.; Jajpura, L.; J. Text. Sci. Eng. 2015, 5, 1.

32. Fan, J.-B.; Wu, L.-P.; Chen, L.-S.; Mao, X.-Y.; Ren, F.-Z.; J. Food Biochem. 2009, 33, 74.

33. Kedare, S. B.; Singh, R. P.; J. Food Sci. Technol. 2011, 48, 412.

34. Yang, T.: Mechanical and Swelling Properties of Hydrogels; $\mathrm{PhD}$ thesis, Chemical Science and Engineering-KTH Royal Institute of Technology, Stockholm, 2012, available at http:// kth.diva-portal.org/smash/record.jsf?pid=diva2\%3A571374\& dswid=-5423, accessed in October 2019.

35. Bourtoom, T.; Songklanakarin J. Sci. Technol. 2008, 30 (Suppl.1), 149.

36. Rippon, M.; White, R.; Davies, P.; Wounds UK 2007, 3, 76.

37. Pal, K.; Banthia, A. K.; Majumdar, D. K.; Des. Monomers Polym. 2009, 12, 197.

38. Boateng, J. S.; Matthews, K. H.; Stevens, H. N. E.; Eccleston, G. M.; J. Pharm. Sci. 2008, 97, 2892.

Submitted: May 2, 2019

Published online: October 21, 2019 